OPEN ACCESS

Edited by:

Jacopo Dal Corso,

China University of Geosciences

Wuhan, China

Reviewed by:

Joshua Davies,

Université du Québec à Montréal,

Canada

Lawrence Henry Tanner,

Le Moyne College, United States

*Correspondence:

Armin Zeh

armin.zeh@kit.edu

Specialty section:

This article was submitted to Sedimentology, Stratigraphy and

Diagenesis,

a section of the journal

Frontiers in Earth Science

Received: 17 September 2021

Accepted: 29 November 2021

Published: 15 December 2021

Citation:

Zeh A, Franz M and Obst K (2021) Zircon of Triassic Age in the Stuttgart Formation (Schilfsandstein) - Witness

of Tephra Fallout in the Central European Basin and New Constraints

on the Mid-Carnian Episode.

Front. Earth Sci. 9:778820.

doi: 10.3389/feart.2021.778820

\section{Zircon of Triassic Age in the Stuttgart Formation (Schilfsandstein) - Witness of Tephra Fallout in the Central European Basin and New Constraints on the Mid-Carnian Episode}

\author{
Armin Zeh ${ }^{1,2 *}$, Matthias Franz $^{3}$ and Karsten Obst ${ }^{4}$ \\ ${ }^{1}$ Mineralogy and Petrology, Institute for Applied Geosciences, Karlsruhe Institute of Technology (KIT), Karlsruhe, Germany, \\ ${ }^{2}$ Frankfurt Isotope and Element Research Center (FIERCE), Goethe-University, Frankfurt, Germany, ${ }^{3}$ Abteilung Angewandte \\ Geologie, Geowissenschaftliches Zentrum der Georg-August-Universität Göttingen, Göttingen, Germany, ${ }^{4}$ Geological Survey of \\ Mecklenburg-Western Pomerania, LUNG M-V, Güstrow, Germany
}

The Carnian Stuttgart-Formation (Schilfsandstein) of the Central European Basin contains relics of Triassic volcanic detritus in form of euhedral zircon grains and authigenic analcime. Multiple LA-ICP-MS spot analyses of single zircon crystals from an outcrop near Heillbronn (SW Germany) yielded weighted average ${ }^{206} \mathrm{~Pb} /{ }^{238} \mathrm{U}$ ages between 250 and $230 \mathrm{Ma}$, providing evidence for tephra fallout in the southern part of the Central European Basin related to Olenekian, Anisian-Ladinian and Carnian volcanic activity. The tephra was probably transported by monsoonal circulations from volcanic centres of the NW Tethys to the Central European Basin. The four youngest zircon crystals gave a weighted average ${ }^{206} \mathrm{~Pb} /{ }^{238} \mathrm{U}$ age of $231.1 \pm 1.6 \mathrm{Ma}$ (10 analyses), which is interpreted to date syndepositional tephra fallout into the fluvial Lower Schilfsandstein Member of the Stuttgart Formation. This new maximum depositional age provides the first evidence that deposition of the Stuttgart Formation, which represents the type-example of the midCarnian episode, a global episode of enhanced flux of siliciclastic detritus and related environmental perturbations, occurred during the Tuvalian 2 substage at ca. $231 \mathrm{Ma}$, about 3 million years later than suggested by previous correlations. Zircon grains with weighted average ${ }^{206} \mathrm{~Pb} /{ }^{238} \mathrm{U}$ ages of $236.0 \pm 1.2 \mathrm{Ma}(n=17)$ and $238.6 \pm 1.5 \mathrm{Ma}(n=6)$ and ${ }^{206} \mathrm{~Pb} /{ }^{238} \mathrm{U}$ ages between $241 \pm 6$ and $250 \pm 3$ Ma point to the presence of tephra in early Carnian to Olenekian strata of the Keuper to Buntsandstein Groups. Traces of these reworked tephra were incorporated into the Stuttgart Formation due to fluvial erosion in the southern Central European Basin and at its margins.

Keywords: zircon, U-Pb data, tephra, Keuper, Stuttgart Formation (Schilfsandstein), Carnian

\section{INTRODUCTION}

Presently, correlations of the terrestrial-marine Keuper Group of the Germanic Upper Triassic with stages of the international Triassic standard (overviews in Bachmann and Kozur, 2004; Franz et al., 2018a) are based on biostratigraphic control using spinicaudatans (conchostracans) and palynomorphs (Heunisch, 1999; Kozur and Weems, 2007; Kozur and Weems, 2010; Geyer and 


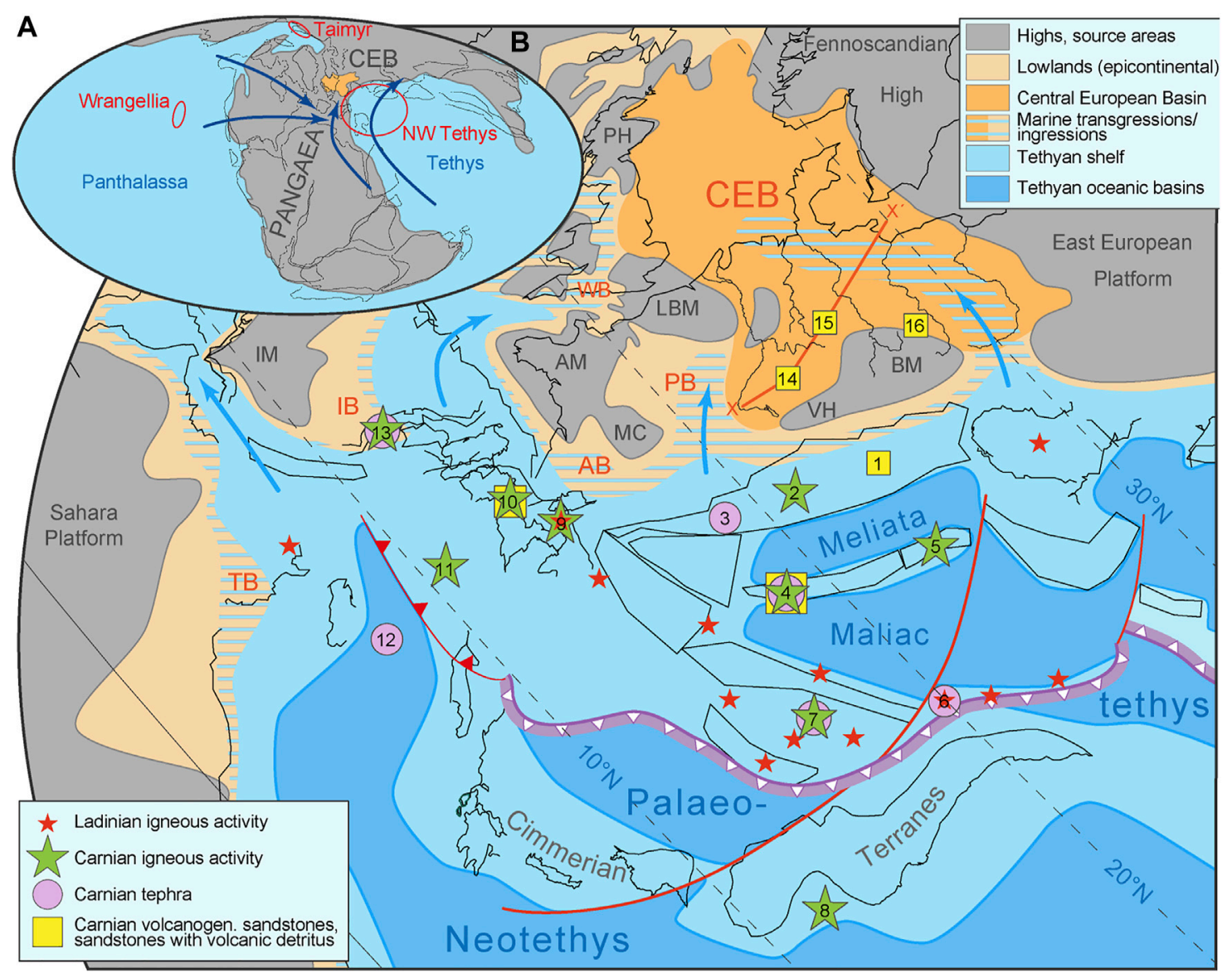

FIGURE 1 | Ladinian-Carnian global and regional palaeogeography. A. Global palaeogeography with the positions of the Central European Basin (CEB), the NW Tethys igneous province, and the Taimyr and Wrangellia Large Igneous Provinces; circulation pattern of northern summer monsoon (blue arrows) after Parrish (1999). B. Regional palaeogeography of the NW Tethys and peri-Tethyan lowlands (modified from Stampfli and Borel, 2004). The CEB is shown at the stage of the Lower Schilfsandstein Member; for cross-section X-X' see Figure 2. Centres of Ladinian and Carnian igneous activity were adopted from Stampfli and Borel (2004): 1 - W Carpathians (Lunz Sandstone: Kohut et al., 2018); 2-North Karawank Mountains (Eisenkappel: Dunkl et al., 2019); 3-Drau Range (Nötsch tuff: Dunkl et al., 2019); 4-Transdanubian Range (Dunkl et al., 2019); 5-Bükk Mountains (Dunkl et al., 2019); 6-Huğlu-Pindos (SW Turkey, Lycian nappes: Moix et al., 2013); 7-Pindos basal sequence (E Crete, Priolithos Fm: Stampfli et al., 2003); 8-Kara Dere Basalt (SW Turkey, Antalya nappes: Maury et al., 2008); 9-Dolomites (Predazzo: e.g., Dunkl et al., 2019); 10-Lombardy (Val Sabbia sandstone: e.g. Garzanti, 1985; Cassinis et al., 2008); 11 - "Southern mobile belt" (Brusca et al., 1982); 12-Lagonegro Basin (Aglianico ash bed: Furin et al., 2006); 13-Mallorca (e.g. López-Gómez et al., 2017); 14-CEB (Schilfsandstein at Heilbronn: this study); 15-CEB (Schilfsandstein at Großmonra,Thuringia: Hofmann et al., 2018); 16-CEB (Lisowice bone-bearing horizon, Lipie Ślaskie: Kowal-Linka et al., 2019). AM, Amorican Massif; AB, Aquitaine Basin; BM, Bohemian Massif; IM, Iberian Massif; LBM, London-Brabant Massif; MC, Massif Central; PB, Paris Basin; PH, Pennine High; TB, Tunis Basin; VH, Vindelician High; WB, Wessex Basin.

Kelber, 2018; Heunisch and Wierer, 2021), partly supplemented by magnetostratigraphy and sequence-stratigraphy (e.g., Zhang et al., 2020). However, a more refined correlation with substages of the Triassic standard is limited due to the lack of any Tethyan marker fossils within the Central German Basin (CEB). Furthermore, exact depositional ages of individual formations remain vague owing to the apparent absence of tuff horizons with datable minerals like zircon, commonly used for precise dating of sedimentary successions. This absence is surprising considering the fact that intense Triassic volcanic activity is known from the NW Tethys realm (e.g., Brusca et al., 1982; Cassinis et al., 2008; Marocchi et al., 2008; Beltran-Trivino et al., 2016; Bianchini et al., 2018; Dunkl et al., 2019; Lustrino et al., 2019; Storck et al., 2019), and also postulated for the northern margin of the CEB (e.g.,
Fisher and Mudge, 1990; Ziegler, 1990; van Bergen and Sissingh, 2007; Larsen et al., 2008). Significant input of Carnian volcanism has recently been reported from marine sandstones of NW Tethyan basins (Kohut et al., 2018; Dunkl et al., 2019), and scarce traces also from a terrestrial sandstone of the Keuper Group in South Poland (Kowal-Linka et al., 2019), while nothing is known so far from wide parts of the CEB.

In this study, we present the first set of Triassic U-Pb ages obtained from euhedral zircon grains of the Stuttgart Formation (Schilfsandstein) from the classical locality Jägerhaus quarry near Heilbronn in SW Germany. Weighted mean ${ }^{206} \mathrm{~Pb} /{ }^{238} \mathrm{U}$ ages obtained from these zircon grains provide the first precise radiometric constraints on the timing of pre- to syndepositional tephra fallout within the southern part of the 
$\mathrm{CEB}$, and on the maximum depositional age of the Stuttgart Formation. As the Stuttgart Formation represents the typeexample of the mid-Carnian episode, a global phase of environmental perturbations and related ecosystem responses (reviews by Arche and López-Gómez, 2014; Ogg, 2015; Ruffell et al., 2015; Dal Corso et al., 2018; Dal Corso et al., 2020, and references therein), the results also have implications for the interpretation of the mid-Carnian episode, in particular for its timing, duration, and international correlation, as will also be discussed here.

\section{GEOLOGICAL SETTING AND STRATIGRAPHIC CONTROL}

\subsection{Geological Setting}

In Triassic times, the CEB was part of the NW peri-Tethys realm, a belt of lowlands bordering the NW Tethys shelf (Figure 1). The basin was filled with detritus delivered from surrounding highs, mainly from Fennoscandian sources to the North and Variscan sources to the South, such as the Vindelician High and/or the Bohemian Massif (Figure 1; e.g., Wurster, 1968; Stollhofen et al., 2008; Bachmann et al., 2010). The tripartite Germanic Triassic is composed from bottom to top of the terrestrial-marine Buntsandstein Group, the marine Muschelkalk Group and the terrestrial-marine Keuper Group (overviews in DSK (Deutsche Stratigraphische Kommission), 2005; DSK (Deutsche Stratigraphische Kommission), 2013; DSK (Deutsche Stratigraphische Kommission), 2020).

Within the Keuper Group, the shaly-sandy Stuttgart Formation (Schilfsandstein) is of basin-wide occurrence and represents a distinct break in the otherwise shaly-evaporitic Keuper sedimentation (e.g., Wurster, 1964; Schröder, 1977; Beutler in DSK (Deutsche Stratigraphische Kommission), 2005; Kozur and Bachmann, 2010). The Stuttgart Formation also represents the type-example of the mid-Carnian episode (Simms and Ruffell, 1989), a global phase characterized by the enhanced influx of siliciclastic detritus into different depositional settings ranging from terrestrial to deep-marine. Various phenomena are considered to be associated with the midCarnian episode, such as pronounced sea-level fluctuations and related oceanographic responses, climate change, faunal turnovers of marine and partly terrestrial groups, and perturbations of the global carbon cycle (see reviews by Arche and López-Gómez, 2014; Ogg, 2015; Ruffell et al., 2015; Dal Corso et al., 2018; Dal Corso et al., 2020 and references therein). The perturbations of the carbon cycle, i.e., sharp negative C-isotope excursions, are considered to have been caused by substantial carbon dioxide exhalations, due to ubiquitous volcanism related to the Wrangellia Large Igneous Province (e.g., Dal Corso et al., 2012; Xu et al., 2014; Dal Corso et al., 2015) and contemporaneous sources like the Taimyr LIP or volcanism in the Tethys realm (Sun et al., 2016; Dal Corso et al., 2018; Lu et al., 2021). Methan release is also discussed as a possible source (Miller et al., 2017).

Due to continuous northwards drift of Pangaea, the latitudinal position of the CEB changed from c. $15^{\circ} \mathrm{N}$ to c. $30^{\circ} \mathrm{N}$ between the
Early and Late Triassic (Stampfli and Borel, 2004). Contemporaneously, the NW Tethys domain underwent fundamental plate tectonic reorganization, resulting from seafloor spreading of the Neotethys, subduction and closure of the Palaeotethys, and opening of back-arc basins (e.g., Stampfli and Borel, 2004). These plate tectonic processes were accompanied by widespread volcanic activity, which is well preserved in the Triassic stratigraphic record, e.g., by the omnipresent Anisian to earliest Carnian Pietra verde ash beds in the Tethys realm (Figure 1; overviews in Lustrino et al., 2019; De Min et al., 2020), and by the middle to late Carnian tuffs and volcanogenic sandstones reported from the NW Tethys domain, i.e., from the Drau Range, North Karawank Mountains, Transdanubian Mountains, South Alpine, and others (e.g., Brusca et al., 1982; Garzanti, 1985; Cassinis et al., 2008; Kohut et al., 2018; Dunkl et al., 2019). One of the best-known example of late Carnian volcanic activity is the Aglianico ash bed of the Calcari con Selce Formation (Lagonegro Basin), which was deposited at $230.91 \pm$ $0.33 \mathrm{Ma}$, as indicated by high-precision CA-ID-TIMS dating (Furin et al., 2006). Despite the temporally intense volcanic activity in the NW Tethys domain, ash beds currently have not been found so far in the early to late Triassic strata of the Buntsandstein to Keuper Groups of the CEB.

The Late Triassic climate was controlled by the Tethys and Panthalassa Oceans and the supercontinent Pangaea (Figure 1), which stretched from the northern to southern polar region and blocked W-E directed exchange of global sea current systems (e.g., Stampfli and Borell, 2004). The stable palaeogeographical configuration and differential heating between the summer hemisphere of Pangaea and the Tethys are considered to have driven monsoonal circulation systems (e.g., Kutzbach and Gallimore, 1989; Parrish, 1993; Wilson et al., 1994; Preto et al., 2010). The lowlands of the NW peri-Tethys realm, including the CEB, were particularly affected by the summer monsoon, which carried moisture from the NW Tethys to the North where Variscan highs acted as orographic barrier (Figure 1; Reinhardt and Ricken, 2000; Kendall et al., 2003; Feist-Burkhardt et al., 2008; Vollmer et al., 2008; McKie, 2017).

\subsection{Stratigraphic Control on the Stuttgart Formation}

Bachmann et al. (1999) and Beutler in DSK (Deutsche Stratigraphische Kommission) (2005) introduced the formal lithostratigraphic term Stuttgart-Formation for the prominent shaly-sandy interval of the Keuper Group traditionally referred to as Schilfsandstein (Jäger, 1827). The Stuttgart Formation comprises a layer-cake architecture of the fluvio-deltaic Lower and Upper Schilfsandstein Members, which are intercalated with the transgressive brackish-marine Neubrandenburg, Gaildorf and Beaumont Members (Figure 2; Franz et al., 2014). The Stuttgart Formation attains an average thickness of $60-70 \mathrm{~m}$ in the northern CEB, but increases locally to more than $100 \mathrm{~m}$ (Beutler and Häusser, 1982; Franz et al., 2018b). Towards the South, the thickness successively decreases to $15-50 \mathrm{~m}$ in Thuringia (e.g., locality Großmonra) and to $3-40 \mathrm{~m}$ in the southern parts of the basin (Figure 2; Dockter and Schubert 


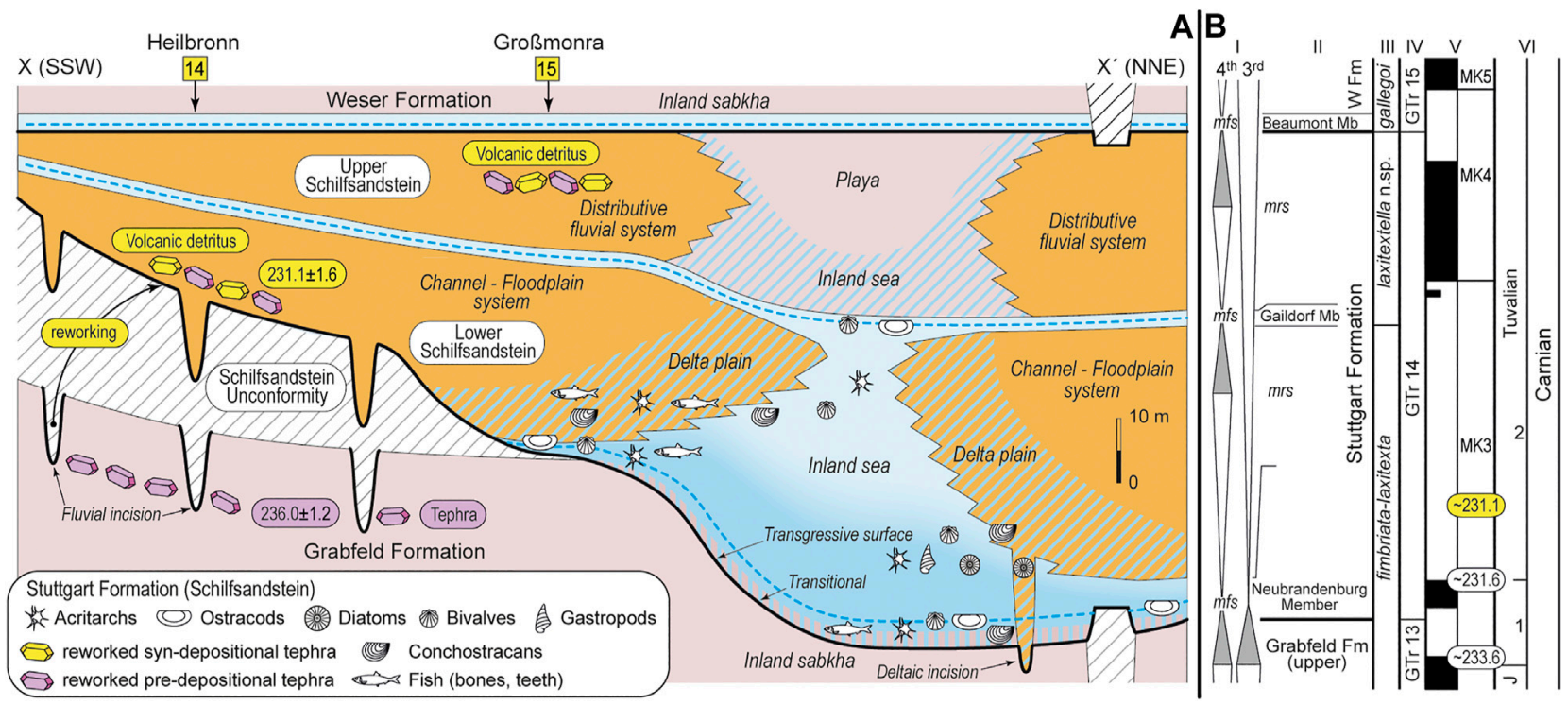

FIGURE 2 | Schematic SSW-NNE cross-section through the Central European Basin summarizing depositional environments (A) and stratigraphy (B) of the Stuttgart Formation (modified from Franz et al., 2018b). Additionally, the stratigraphic position of tephra is shown deposited at $236.0 \pm 1.2 \mathrm{Ma}$ (early Carnian Grabfeld Fm), at $231.1 \pm 1.6 \mathrm{Ma}$ (late Carnian Lower Schilfsandstein Member at Heilbronn, this study), and $231 \pm 5 \mathrm{Ma}$ (Upper Schilfsandstein Member at Großmonra, Hofmann et al., 2018). Due to fluvial incision and reworking of older strata, remnants of pre-depositional tephra were incorporated into fluvial sandstones of the Stuttgart Formation and mixed with syn-depositional tephra. For profile line X-X' see Figure 1. I-third- and fourth-order sequences, II-lithostratigraphy of the Stuttgart Formation (Franz et al., 2014), III-conchostracan biostratigraphy (Kozur and Bachmann, 2010; Geyer and Kellber, 2018), IV-palynostratigraphy (Heunisch, 1999), V-magnetostratigraphy (reinterpreted from Zhang et al., 2020), VI-correlation with Carnian substages, tentatively recalibrated according to the new age presented herein; white boxes - ages substage boundaries (according to Zhang et al., 2020); J-Julian, yellow box: maximum depositional age of the Lower Schilfsandstein Member in SW Germany (this study).

in DSK (Deutsche Stratigraphische Kommission), 2005; Etzold and Schweitzer in DSK (Deutsche Stratigraphische Kommission), 2005). The fluvio-deltaic Lower and Upper Schilfsandstein Members are subject to pronounced lateral facies shifts from sand-prone fluvio-deltaic channels to shaly floodplain, delta plain and inland sea environments (overviews in Wurster, 1964; Kozur and Bachmann, 2010; Franz et al., 2018b). These shaly successions are $3-15 \mathrm{~m}$ thick in the southern CEB but up to $70 \mathrm{~m}$ thick in the northern CEB and yielded remnants of terrestrial to marine vertebrate and invertebrate faunas (overviews in Etzold and Schweitzer in DSK (Deutsche Stratigraphische Kommission), 2005; Kozur and Bachmann, 2010; Franz et al., 2018b). Apart from authigenic analcime, considered the diagenetic product of volcanic ash (e.g., Hay, 1966; Füchtbauer, 1974; Kühn, 1976), remnants of tephra or ash beds could not be observed, neither in sandstones of the channel facies nor in shales of overbank environments.

Corresponding to the higher thickness in the northern CEB, the change from the shaly-evaporitic Grabfeld Formation to the Stuttgart Formation is transitional and therefore, can be considered continuous (overviews in Franz et al., 2018b; Franz and Barnasch, 2021). In contrast to this, the transitional interval and the transgressive brackish-marine Neubrandenburg Member are missing in the southern $\mathrm{CEB}$ resulting in a sharp and discontinuous boundary between the Grabfeld and Stuttgart Formations. The gap associated to this boundary increases when fluvial channels of the Lower Schilfsandstein Member are incised into the upper Grabfeld Formation (Figure 2). A particular good example of an incised valley fill (c.f. Aigner and Bachmann, 1992) is exposed at Heilbronn where a fluvial channel cuts about $9 \mathrm{~m}$ deep into the upper Grabfeld Formation (Bachmann and Wild, 1976). Comparable erosional gaps associated to the Schilfsandstein Unconformity (Franz et al., 2018b) were described from the northern basin margins and from basin-internal swells (overviews in Beutler, 1995; Franz, 2008; Barnasch, 2010).

As marine index fossils of Tethyan biozones are lacking in the Stuttgart Formation, biostratigraphic control is provided by conchostracans, ostracods and palynomorphs (Figure 2; Heunisch, 1999; Kozur and Bachmann, 2010; Kozur and Weems, 2010). The zonations based on conchostracans and palynomorphs are only valid in the CEB (Heunisch, 1999; Kozur and Weems, 2010; Geyer and Kelber, 2018), but the occurrence of the ostracod Simeonella alpina enables the tentative correlation with Tethyan strata. As S. alpina is restricted to the late Julian Austrotrachyceras austriacum Zone of the NW Tethys, Bachmann and Kozur (2004), and Kozur and Bachmann (2010) correlated the Stuttgart Formation with the North Alpine Reingraben Shales/Lunz Formation and contemporaneous Tethyan strata. Since, this preliminary correlation has been accepted and provided the basis for sequence-stratigraphic and magnetostratigraphic correlations of the Stuttgart Formation (Franz et al., 2014; Zhang et al., 2020). Recently, Zhang et al. (2020) proposed a composite 


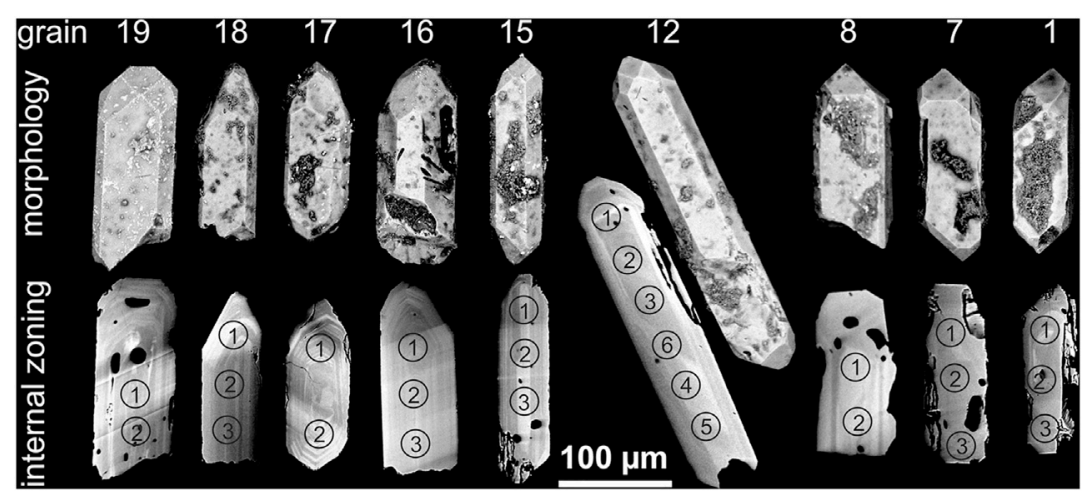

FIGURE 3 | Morphology and internal zoning of dated zircon grains of sandstone sample Heilb-1 from the Jägerhaus quarry near Heilbronn (all back scattered electron images). Circles mark laser spot positions; numbers refer to Table $\mathbf{1}$

Carnian magnetostratigraphy covering larger parts of the Keuper Group including the Stuttgart Formation. Zhang et al. (2020) correlated the biostratigraphically calibrated magnetic polarity pattern of the Stuttgart Formation with an about 1 myr long interval between c. 234-233 Ma ranging from the Julian 2 to lower Tuvalian 1, which largely corresponds to previous correlations (Kozur and Bachmann 2010; Franz et al., 2014). The short time-span of the Stuttgart Formation is in congruence with estimated durations of about $0.8 \mathrm{Ma}$ according to Kozur and Bachmann (2010) and about 1.2 Ma according to Miller et al. (2017).

\section{SAMPLES AND METHODS}

\subsection{Sample Description}

The investigated sample Heilb-1 represents a medium-to finegrained, brownish, homogeneous sandstone of the Lower Schilfsandstein Member exposed in the Jägerhaus quarry east of Heilbronn in SW Germany (co-ordinates: N 48 $08^{\prime} 07.96^{\prime \prime}, \mathrm{E}$ $\left.9^{\circ} 16^{\prime} 02.70^{\prime \prime}\right)$. The detritus of the sample is immature and consists mostly of angular, poorly rounded fragments of monocrystalline quartz, K-feldspar, plagioclase, white micas and lithic components, thoroughly cemented by interstitial quartz, illite/ smectite and Fe-oxides/hydroxides, and contains accessory zircon, apatite and ilmenite. These minerals are confirmed by detailed thin section survey and XRD analyses. Evidence for the existence of authigenic analcime has not been found in our sample, but is described from many other localities in the Central European Basin (see Kühn, 1976; Förster et al., 2010; Franz et al., 2018b; Franz et al., 2019).

\subsection{Methods}

The sample was crushed with a jaw crusher and disc mill to $<500 \mu \mathrm{m}$, and the heavy minerals enriched by panning, Frantz magnetic separator, and finally handpicked under ethanol (all at KIT Karlsruhe). The separated zircon grains were mounted on double-sided tape, coated with gold and their morphologies photographed by means of scanning electron microscope (TESCAN VEGA2 SBH with Oxford SwiftED EDX-system).
Subsequently, the grains were embedded with epoxy resin in 1 -inch plastic rings, ground and polished to expose their center parts, and the internal structures analyzed by back scattered electron imaging (Figure 3). During a first session, about 130 zircon grains, independent of their shapes (ranging from round to needle-like euhedral) were analyses for $\mathrm{U}-\mathrm{Th}-\mathrm{Pb}$ isotopes using single laser spots to get information about general age variations. During a second session, up to five additional laser spots were placed on single zircon crystals already measured during the first session, in particular grains of Triassic age. In addition, a new set of 30 euhedral zircon crystals, most of needle-like shape (aspect ratios $=2$ to 5 ; Table 1 ) were measured by up to four spot analyzes. The multiple analyses were done with the aim to gain information about intra-grain age variations related to $\mathrm{Pb}$ loss. All $\mathrm{U}-\mathrm{Th}-\mathrm{Pb}$ isotopes were measured by means of a Resonetics M50 $193 \mathrm{~nm}$ Excimer laser system, coupled to a Thermo-Scientific ELEMENT XR at Goethe University Frankfurt, Germany, using the same methods as described by Gerdes and Zeh (2009) with modifications given in Zeh and Gerdes (2012). During both sessions, data were acquired with 20- and 16-s measurements for background and sample ablation, respectively. Laser spot-size was $26 \mu \mathrm{m}$ for unknown and primary reference material (zircon GJ1), as well as secondary reference materials (zircon BB and Plesoviče). Ablation was performed in a $\mathrm{He}$ stream $(0.33 \mathrm{~L} / \mathrm{min})$, which was mixed directly after the ablation cell with $\mathrm{N}_{2}$ and $\mathrm{Ar}$, $0.006 \mathrm{~L} / \mathrm{min}$ and $0.89 \mathrm{~L} / \mathrm{min}$, respectively, prior to introduction into the Ar plasma of the SF-ICP-MS. The signal was tuned for maximum sensitivity for $\mathrm{Pb}$ and $\mathrm{U}$ while keeping oxide production, monitored as ${ }^{254}(\mathrm{UO}) /{ }^{238} \mathrm{U}$, below $0.3 \%$. The sensitivity achieved was in the range of $9,900 \mathrm{cps}(\mu \mathrm{g} / \mathrm{g})^{-1}$ for ${ }^{238} \mathrm{U}$ with a $26-\mu \mathrm{m}$ spot size, at $5.5 \mathrm{~Hz}$ and about $2.8 \mathrm{~J} / \mathrm{cm}^{2}$ laser energy. The typical penetration depth was about $15 \mu \mathrm{m}$. Detailed instrument and processing parameters are presented in Supplementary Table S1.

Raw data were corrected offline for background signal, common $\mathrm{Pb}$, laser-induced elemental fractionation, instrumental mass discrimination, and time-dependent elemental fractionation of $\mathrm{Pb} / \mathrm{U}$ using an in-house MS Excel $^{\odot}$ spreadsheet program (Gerdes and Zeh, 2006; Gerdes and Zeh, 2009). A common-Pb correction was carried out based on the interference- and 
TABLE 1 | Results of U-Pb zircon dating and zircon size measurements.

\begin{tabular}{|c|c|c|c|c|c|c|c|c|c|c|c|c|c|c|c|c|c|c|c|c|c|c|}
\hline $\begin{array}{l}\text { Grain/ } \\
\text { analysis }\end{array}$ & $\frac{{ }^{207} \mathrm{pb}^{\mathrm{a}}}{(\mathrm{cps})}$ & $\frac{U^{b}}{(\mathbf{p p m})}$ & $\frac{\mathrm{pb}^{\mathrm{b}}}{(\mathrm{ppm})}$ & $\frac{T h^{b}}{U}$ & $\frac{{ }^{206} \mathrm{pbc}^{\mathrm{c}}}{(\%)}$ & 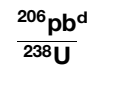 & $\frac{ \pm 2 \sigma}{(\%)}$ & $\frac{{ }^{207} \mathbf{p b}^{d}}{{ }^{d} \mathbf{U} U}$ & $\frac{ \pm 2 \sigma}{(\%)}$ & ${\frac{}{207} \mathrm{pb}^{\mathrm{d}}}^{{ }^{206} \mathrm{pb}}$ & $\frac{ \pm 2 \sigma}{(\%)}$ & rho $^{e}$ & $\frac{{ }^{206} \mathrm{pb}}{{ }^{238} \mathrm{U}}$ & $\frac{ \pm 2 \sigma}{\text { (Ma) }}$ & $\frac{{ }^{207} \mathrm{pb}}{{ }^{235} \mathrm{U}}$ & $\frac{ \pm 2 \sigma}{\text { (Ma) }}$ & 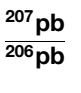 & $\frac{ \pm 2 \sigma}{\text { (Ma) }}$ & $\frac{\text { Conc. }^{f}}{(\%)}$ & $\frac{\text { Length }}{\mu \mathrm{m}}$ & $\frac{\text { Width }}{\mu \mathrm{m}}$ & $\begin{array}{c}\text { Aspect } \\
\text { ratio }\end{array}$ \\
\hline 1-a22-s1 & 45,298 & 568 & 25 & 0.92 & b.d. & 0.03954 & 1.3 & 0.2784 & 1.5 & 0.05106 & 0.6 & 0.91 & 250 & 3 & 249 & 3 & 244 & 14 & 103 & 123 & 60 & 2.1 \\
\hline 1-a11-s1 & 22,440 & 258 & 13 & 1.66 & b.d. & 0.03949 & 1.5 & 0.2925 & 6.2 & 0.05373 & 6.0 & 0.24 & 250 & 4 & 261 & 14 & 360 & 136 & 69 & & & \\
\hline 1-a324 & 10,941 & 236 & 11 & 1.00 & 0.81 & 0.03918 & 2.9 & 0.2775 & 16.2 & 0.05137 & 16 & 0.18 & 248 & 7 & 249 & 36 & 258 & 366 & 96 & & & \\
\hline 2-a289 & 17,915 & 284 & 13 & 0.86 & 1.56 & 0.03906 & 2.9 & 0.2724 & 9.9 & 0.05057 & 9.5 & 0.29 & 247 & 7 & 245 & 22 & 221 & 220 & 112 & 189 & 55 & 3.5 \\
\hline 2-a288 & 14,034 & 320 & 14 & 0.92 & 0.23 & 0.03723 & 2.5 & 0.2625 & 2.8 & 0.05114 & 1.2 & 0.90 & 236 & 6 & 237 & 6 & 247 & 28 & 95 & & & \\
\hline 2-a282 & 12,753 & 306 & 13 & 0.81 & b.d. & 0.03709 & 2.5 & 0.2607 & 2.6 & 0.05097 & 0.9 & 0.94 & 235 & 6 & 235 & 6 & 240 & 21 & 98 & & & \\
\hline 3-a06-s1 & 15,579 & 168 & 8 & 1.12 & 0.63 & 0.03880 & 1.5 & 0.3 & 3.1 & 0.05607 & 2.7 & 0.50 & 245 & 4 & 266 & 7 & 455 & 60 & 54 & $188^{9}$ & 62 & 3.1 \\
\hline 4-a304 & 21,363 & 510 & 22 & 0.78 & b.d. & 0.03829 & 2.4 & 0.2692 & 2.6 & 0.05099 & 0.9 & 0.94 & 242 & 6 & 242 & 6 & 240 & 20 & 101 & $154^{\mathrm{g}}$ & 60 & 2.6 \\
\hline 4-a305 & 25,027 & 576 & 23 & 0.49 & 0.11 & 0.03735 & 2.5 & 0.2665 & 2.8 & 0.05176 & 1.2 & 0.91 & 236 & 6 & 240 & 6 & 275 & 27 & 86 & & & \\
\hline 4-a303 & 32,173 & 782 & 33 & 1.09 & b.d. & 0.03628 & 2.4 & 0.257 & 2.5 & 0.05139 & 0.7 & 0.96 & 230 & 6 & 232 & 5 & 258 & 16 & 89 & & & \\
\hline 5-a299 & 11,413 & 263 & 12 & 1.15 & 0.18 & 0.03802 & 2.5 & 0.2673 & 2.9 & 0.05099 & 1.3 & 0.89 & 241 & 6 & 241 & 6 & 240 & 30 & 100 & 197 & 75 & 2.6 \\
\hline 5-a301 & 8,532 & 193 & 8 & 0.81 & 0.19 & 0.03697 & 2.5 & 0.2658 & 3.1 & 0.05216 & 1.8 & 0.80 & 234 & 6 & 239 & 7 & 292 & 42 & 80 & & & \\
\hline 5-2300 & 9,174 & 224 & 10 & 1.07 & 0.16 & 0.03666 & 2.6 & 0.2541 & 2.8 & 0.05028 & 1.1 & 0.92 & 232 & 6 & 230 & 6 & 208 & 26 & 112 & & & \\
\hline 6-a41-s1 & 18,761 & 220 & 10 & 1.30 & 0.10 & 0.03786 & 1.8 & 0.2723 & 2.0 & 0.05216 & 0.9 & 0.90 & 240 & 4 & 245 & 4 & 293 & 20 & 82 & $133^{9}$ & 53 & 2.5 \\
\hline 7-a41 & 19,799 & 399 & 17 & 0.88 & 0.77 & 0.03799 & 1.4 & 0.2662 & 5.8 & 0.05081 & 5.7 & 0.24 & 240 & 3 & 240 & 13 & 232 & 131 & 104 & 168 & 51 & 3.3 \\
\hline 7-a42 & 19,114 & 378 & 16 & 0.68 & 1.38 & 0.03795 & 1.6 & 0.256 & 7.1 & 0.04891 & 6.9 & 0.23 & 240 & 4 & 231 & 15 & 144 & 161 & 167 & & & \\
\hline 7-a40 & 19,709 & 410 & 17 & 0.80 & b.d. & 0.03734 & 1.2 & 0.2651 & 1.4 & 0.05148 & 0.7 & 0.85 & 236 & 3 & 239 & 3 & 263 & 17 & 90 & & & \\
\hline 8-a318 & 12,939 & 312 & 13 & 0.58 & b.d. & 0.03774 & 2.4 & 0.2657 & 2.6 & 0.05107 & 0.9 & 0.94 & 239 & 6 & 239 & 6 & 244 & 21 & 98 & $211^{\mathrm{g}}$ & 67 & 3.2 \\
\hline 8-a317 & 5,847 & 141 & 6 & 0.63 & 0.07 & 0.03748 & 2.5 & 0.2637 & 3.0 & 0.05103 & 1.8 & 0.81 & 237 & 6 & 238 & 6 & 242 & 40 & 98 & & & \\
\hline 9-a27 & 19,634 & 355 & 15 & 0.86 & 0.48 & 0.03771 & 1.3 & 0.2639 & 5.5 & 0.05075 & 5.3 & 0.24 & 239 & 3 & 238 & 12 & 230 & 123 & 104 & 211 & 68 & 3.1 \\
\hline 9-a26 & 25,725 & 525 & 22 & 0.91 & 0.55 & 0.03748 & 1.2 & 0.2585 & 5.3 & 0.05003 & 5.2 & 0.23 & 237 & 3 & 233 & 11 & 197 & 120 & 121 & & & \\
\hline 9-a64-s1 & 20,935 & 374 & 15 & 0.57 & 1.99 & 0.03742 & 1.6 & 0.2605 & 5.9 & 0.05048 & 5.7 & 0.27 & 237 & 4 & 235 & 12 & 217 & 131 & 109 & & & \\
\hline 9-a28 & 39,309 & 493 & 20 & 0.72 & 0.13 & 0.03653 & 1.4 & 0.2584 & 1.7 & 0.05129 & 0.8 & 0.86 & 231 & 3 & 233 & 4 & 254 & 20 & 91 & & & \\
\hline 10-a89-s1 & 54,254 & 688 & 28 & 0.62 & b.d. & 0.03768 & 1.5 & 0.268 & 1.7 & 0.05159 & 0.8 & 0.88 & 238 & 4 & 241 & 4 & 267 & 19 & 89 & $134^{9}$ & 67 & 2.0 \\
\hline 10-a24 & 35,482 & 749 & 29 & 0.64 & 1.10 & 0.03659 & 1.2 & 0.241 & 5.2 & 0.04777 & 5 & 0.23 & 232 & 3 & 219 & 10 & 88 & 119 & 263 & & & \\
\hline 11-a101-s1 & 7,724 & 96 & 4 & 0.57 & 2.26 & 0.03759 & 2.6 & 0.2641 & 4.9 & 0.05095 & 4.2 & 0.53 & 238 & 6 & 238 & 11 & 239 & 97 & 100 & $122^{\mathrm{g}}$ & 68 & 1.8 \\
\hline $12-a 16$ & 10,178 & 205 & 9 & 0.92 & 0.01 & 0.03765 & 1.3 & 0.2645 & 1.7 & 0.05096 & 1 & 0.80 & 238 & 3 & 238 & 4 & 239 & 23 & 100 & 368 & 71 & 5.2 \\
\hline 12-a19 & 7,747 & 161 & 7 & 0.86 & 0.01 & 0.03740 & 1.5 & 0.2628 & 2.0 & 0.05096 & 1.4 & 0.75 & 237 & 4 & 237 & 4 & 239 & 31 & 99 & & & \\
\hline 12-a18 & 8,651 & 187 & 8 & 0.85 & 0.01 & 0.03718 & 1.2 & 0.2607 & 1.6 & 0.05084 & 1.1 & 0.75 & 235 & 3 & 235 & 3 & 234 & 25 & 101 & & & \\
\hline 12-a17 & 9,695 & 207 & 9 & 0.88 & 0.07 & 0.03701 & 1.2 & 0.2585 & 1.7 & 0.05065 & 1.2 & 0.71 & 234 & 3 & 233 & 4 & 225 & 28 & 104 & & & \\
\hline 12-a15 & 18,128 & 363 & 15 & 1.05 & 2.61 & 0.03659 & 1.4 & 0.2467 & 8.8 & 0.04889 & 8.7 & 0.15 & 232 & 3 & 224 & 18 & 143 & 205 & 162 & & & \\
\hline 12-a127-s1 & 12,949 & 142 & 6 & 0.86 & b.d. & 0.03545 & 2.4 & 0.2474 & 2.8 & 0.05062 & 1.4 & 0.86 & 225 & 5 & 224 & 6 & 223 & 33 & 101 & & & \\
\hline 13-a57 & 9,254 & 195 & 8 & 0.82 & 2.11 & 0.03767 & 2.0 & 0.2604 & 11.5 & 0.05014 & 11 & 0.17 & 238 & 5 & 235 & 24 & 202 & 264 & 118 & $145^{9}$ & 72 & 2.0 \\
\hline 13-a56 & 11,252 & 176 & 7 & 0.76 & 4.06 & 0.03745 & 2.2 & 0.2623 & 13.2 & 0.05081 & 13 & 0.17 & 237 & 5 & 237 & 28 & 232 & 301 & 102 & & & \\
\hline 13-a55 & 17,220 & 302 & 13 & 0.82 & 1.58 & 0.03718 & 1.7 & 0.2614 & 8.9 & 0.05099 & 8.8 & 0.19 & 235 & 4 & 236 & 19 & 240 & 202 & 98 & & & \\
\hline 14-a94-s1 & 31,878 & 374 & 16 & 0.87 & 0.50 & 0.03747 & 1.5 & 0.2664 & 2.0 & 0.05156 & 1.4 & 0.74 & 237 & 3 & 240 & 4 & 266 & 31 & 89 & $156^{g}$ & 61 & 2.6 \\
\hline 15-а322 & 10,142 & 220 & 9 & 0.97 & 1.13 & 0.03730 & 2.8 & 0.2623 & 15.1 & 0.05101 & 15 & 0.18 & 236 & 6 & 237 & 32 & 241 & 343 & 98 & 206 & 54 & 3.9 \\
\hline 15-а321 & 18,589 & 327 & 15 & 1.09 & 1.80 & 0.03707 & 2.5 & 0.2931 & 3.8 & 0.05735 & 2.9 & 0.65 & 235 & 6 & 261 & 9 & 505 & 63 & 46 & & & \\
\hline 15-а320 & 18,223 & 458 & 20 & 1.18 & b.d. & 0.03625 & 2.4 & 0.2559 & 2.5 & 0.0512 & 0.7 & 0.96 & 230 & 5 & 231 & 5 & 250 & 16 & 92 & & & \\
\hline 16-a310 & 9,218 & 227 & 10 & 1.39 & 0.01 & 0.03675 & 2.5 & 0.2575 & 2.6 & 0.05083 & 1 & 0.93 & 233 & 6 & 233 & 6 & 233 & 23 & 100 & $220^{9}$ & 89 & 2.5 \\
\hline 16-a311 & 10,120 & 256 & 11 & 1.19 & 0.05 & 0.03660 & 2.4 & 0.2562 & 2.7 & 0.05076 & 1.2 & 0.89 & 232 & 6 & 232 & 6 & 230 & 28 & 101 & & & \\
\hline 16-а312 & 14,869 & 357 & 15 & 1.07 & 0.02 & 0.03672 & 2.4 & 0.2599 & 2.6 & 0.05133 & 0.9 & 0.94 & 232 & 6 & 235 & 5 & 255 & 20 & 91 & & & \\
\hline 17-a342 & 26,801 & 678 & 26 & 0.58 & b.d. & 0.03662 & 2.4 & 0.2563 & 2.5 & 0.05076 & 0.7 & 0.96 & 232 & 6 & 232 & 5 & 230 & 15 & 101 & 189 & 69 & 2.7 \\
\hline $17-\mathrm{a} 343$ & 16,847 & 405 & 15 & 0.43 & 0.09 & 0.03614 & 2.5 & 0.2556 & 2.6 & 0.05128 & 1 & 0.93 & 229 & 6 & 231 & 5 & 253 & 22 & 90 & & & \\
\hline 18-a295 & 39,309 & 493 & 20 & 0.72 & 0.13 & 0.03653 & 1.4 & 0.2584 & 1.7 & 0.05129 & 0.8 & 0.86 & 231 & 3 & 233 & 4 & 254 & 20 & 91 & $180^{9}$ & 59 & 3.0 \\
\hline 18-a296 & 7,868 & 197 & 9 & 1.35 & b.d. & 0.03643 & 2.5 & 0.2558 & 2.7 & 0.05092 & 1.1 & 0.92 & 231 & 6 & 231 & 6 & 237 & 24 & 97 & & & \\
\hline 18-a297 & 7,977 & 175 & 8 & 1.29 & 0.09 & 0.03642 & 2.5 & 0.2553 & 3.0 & 0.05084 & 1.5 & 0.85 & 231 & 6 & 231 & 6 & 233 & 36 & 99 & & & \\
\hline
\end{tabular}




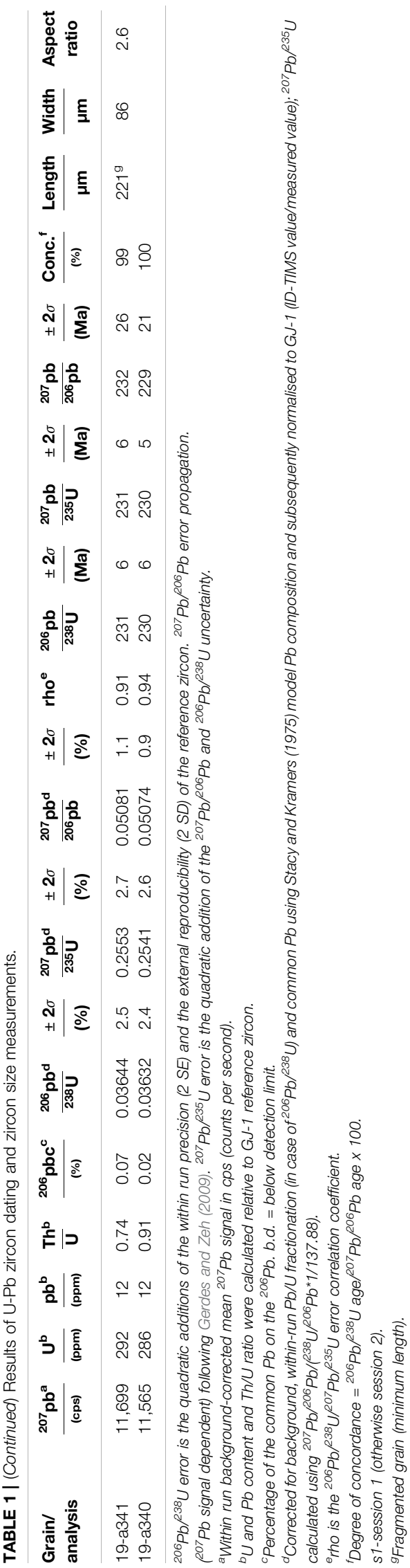

background-corrected ${ }^{204} \mathrm{~Pb}$ signal and a model $\mathrm{Pb}$ composition (Stacey and Kramers, 1975). Calculated common ${ }^{206} \mathrm{~Pb}$ contents in samples is mostly $<0.2 \%$ of the total ${ }^{206} \mathrm{~Pb}$, but in rare cases exceeded 1.5\% (Table 1). Laser-induced elemental fractionation and instrumental mass discrimination were corrected by normalization to the reference zircon GJ-1 (Jackson et al., 2004), as well as inter-elemental fractionation $\left({ }^{206} \mathrm{~Pb}^{\star} /{ }^{238} \mathrm{U}\right)$ during sample ablation. Corrected drift during the analytical sessions was between 2 and $6 \%$. Reported uncertainties $(2 \sigma)$ of the ratio were propagated by quadratic addition of the external reproducibility (2 S.D., standard deviation), obtained from the reference zircon GJ-1 and the within-run precision of each analysis (2 S.E., standard error). For the ratio ${ }^{207} \mathrm{~Pb} /{ }^{206} \mathrm{~Pb}$, we used $\mathrm{a}^{207} \mathrm{~Pb}$ signal-dependent uncertainty propagation (Gerdes and Zeh, 2009). The ratio ${ }^{207} \mathrm{~Pb} /{ }^{235} \mathrm{U}$ is derived from the normalized and errorpropagated ratios ${ }^{207} \mathrm{~Pb} /{ }^{206} \mathrm{~Pb}^{*}$ and ${ }^{206} \mathrm{~Pb}^{*} /{ }^{238} \mathrm{U}$, assuming a natural abundance ratio of ${ }^{238} \mathrm{U} /{ }^{235} \mathrm{U}=137.818$ (Hiess et al., 2012) and the uncertainty derived by quadratic addition of the propagated uncertainties of both ratios.

Accuracy was verified by multiple analyses of two secondary reference materials, which yielded Concordia ages for the Plesoviče zircon of $337.9 \pm 1.1 \mathrm{Ma}$ (session 1: MSWD $_{\mathrm{C} .+\mathrm{E} \text {. }}=$ 0.97 , Probability ${ }_{\mathrm{C} .+\mathrm{E} .}=0.52, n=26$; C. + E. - concordance and equivalence) and $337.8 \pm 2.3 \mathrm{Ma}$ (session $2: \mathrm{MSWD}_{\mathrm{C} . \mathrm{E} .}=0.76$, Probability $_{\mathrm{C}+\mathrm{E} .}=0.75, n=10$ ), and for $\mathrm{BB}$ zircon of $563.5 \pm$ $2.5 \mathrm{Ma}$ (session 1: MSWD $_{\mathrm{C} .+\mathrm{E} .}=0.89$, Probability ${ }_{\mathrm{C} . \mathrm{E} .}=0.60$, $n=10$ ), and $561.1 \pm 1.2 \mathrm{Ma}$ (session 2: $\mathrm{MSWD}_{\mathrm{C} .+\mathrm{E} .}=1.08$, Probability $\left.{ }_{\mathrm{C} . \mathrm{E} .}=0.29, n=38\right)$, in agreement with the quoted LA-ICP-MS value of $562 \pm 9$ Ma for the BB zircon $\left({ }^{206} \mathrm{~Pb} /{ }^{238} \mathrm{U}\right.$; Santos et al., 2017), and with the quoted TIMS value of $337.13 \pm$ 0.37 Ma for the Plesoviče zircon (Sláma et al., 2008). Data were plotted using the software ISOPLOT (Ludwig, 2001). Results of $\mathrm{U}-\mathrm{Th}-\mathrm{Pb}$ isotope measurements are presented in Table $\mathbf{1}$, and of the reference zircons in Supplementary Table S2.

\section{RESULTS}

During this study about 160 zircon grains, comprising 50 grains of euhedral habitus were analyzed for $\mathrm{U}-\mathrm{Th}-\mathrm{Pb}$ isotope compositions. Nineteen of these grains yielded Triassic ages. These are the ones that will be discussed further in this study. The shapes of the Triassic zircon grains vary from short-prismatic stubby to needle-like, with lengths ranging from c. $125-370 \mu \mathrm{m}$, and aspect ratios from 1.8 to 5.2 , although some elongated grains represent broken fragments (Figure 3; Table 1). Most grains show oscillatory or banded internal zoning (Figure 3), and Th/U ratios between 0.43 and 1.66 (Table 1), both features typical for zircon crystals formed in magmatic environments. The ${ }^{206} \mathrm{~Pb} /$ ${ }^{238} \mathrm{U}$ ages obtained by single-spot analyses from the Triassic zircon grains range from $250 \pm 3 \mathrm{Ma}$ to $230 \pm 6 \mathrm{Ma}$ (Table 1) Multiple analyses carried out on individual zircon crystals, i.e., 2-6 analyses per grain, gave in most cases identical dates, within error, allowing calculation of weighted average ${ }^{206} \mathrm{~Pb} /{ }^{238} \mathrm{U}$ ages (Figure 4). Significant differences between the oldest and youngest ${ }^{206} \mathrm{~Pb} /{ }^{238} \mathrm{U}$ age values were only observed in a few grains (e.g., grains 10,12). For these crystals, the youngest ages were 


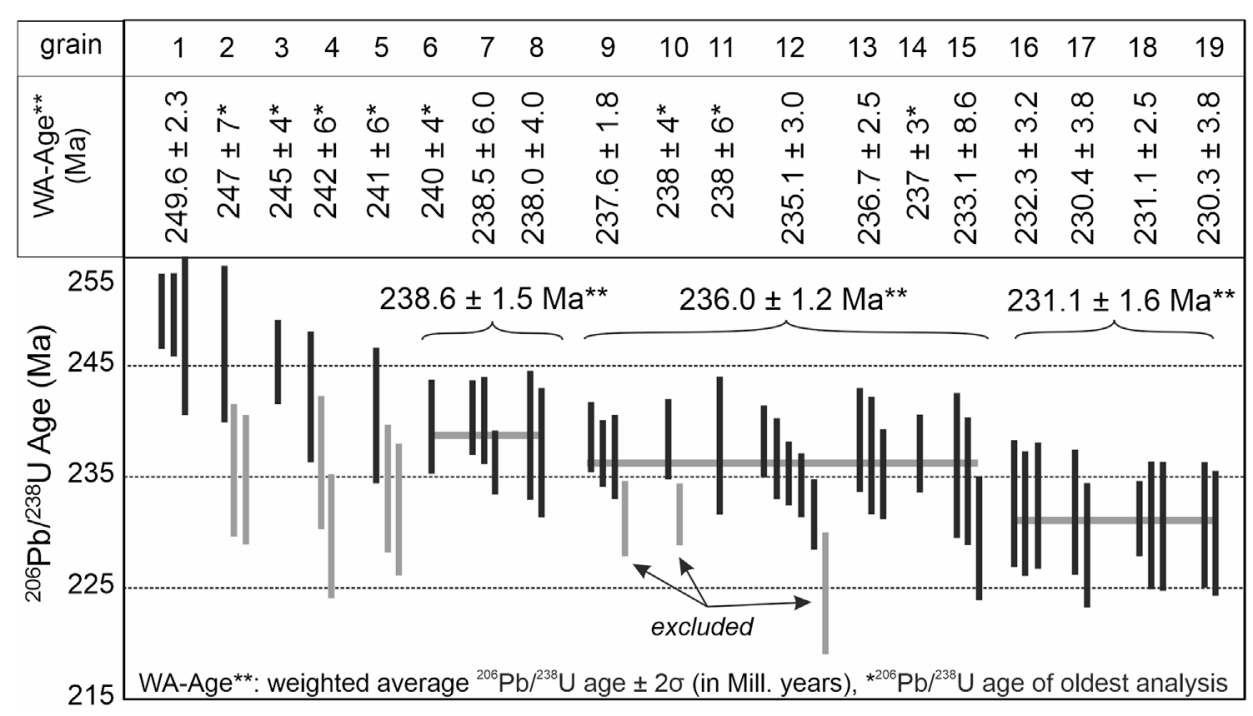

FIGURE 4 | Results of U-Pb dating of the nineteen youngest detrital zircon grains of euhedral shape separated from the sandstone sample Heilb-1. Weighted average ages were calculated from multiple analyses of individual zircon grains $\left({ }^{\star}\right)$, or from analyses of several grains $\left(^{\star \star}\right)$. Excluded analyses (grey bars) are assumed to represent outliers due to significant $\mathrm{Pb}$ loss.

considered to have been reset by $\mathrm{Pb}$ loss and excluded from weighted average ${ }^{206} \mathrm{~Pb} /{ }^{238} \mathrm{U}$ age calculations.

Analyses of the four youngest zircon crystals (grains 16-19) yield weighted average ${ }^{206} \mathrm{~Pb} /{ }^{238} \mathrm{U}$ ages of $230.3 \pm 3.8 \mathrm{Ma}$ (grain $19 ; n=2$ ), $230.4 \pm 3.8 \mathrm{Ma}$ (grain $17 ; n=2$ ), $231.1 \pm 2.5 \mathrm{Ma}$ (grain $18 ; n=3$ ), and $232.3 \pm 3.2 \mathrm{Ma}$ (grain $16 ; n=3$ ). All ten analyses together reveal a weighted average ${ }^{206} \mathrm{~Pb} /{ }^{238} \mathrm{U}$ age of $231.1 \pm 1.6 \mathrm{Ma}$ (Figure 4), identical to a Concordia age of $231.5 \pm 1.6 \mathrm{Ma}\left(\mathrm{MSWD}_{\mathrm{C} .+\mathrm{E} .}=\right.$ 0.85, Probability C. + . $=0.65 ;$ C. + E. - concordance and equivalence; Figure 5A). This age is significantly younger than that calculated for the seven next older zircon grains (9-15). These give a weighted average ${ }^{206} \mathrm{~Pb} /{ }^{238} \mathrm{U}$ age of $236.0 \pm 1.2 \mathrm{Ma}$ $(n=17)$, identical to a Concordia age of $236.6 \pm 0.9 \mathrm{Ma}\left(\mathrm{MSWD}_{\mathrm{C} .+\mathrm{E} \text {. }}\right.$ $=1.4$, Probability $\left.{ }_{\mathrm{C} .+\mathrm{E} .}=0.16, n=15\right)$ (Figure 5B). Individual weighted average ${ }^{206} \mathrm{~Pb} /{ }^{238} \mathrm{U}$ ages obtained from the grains 9 to 15 range from $233.1 \pm 8.6 \mathrm{Ma}$ to $237.6 \pm 1.8 \mathrm{Ma}$ (Figure 4). The ${ }^{206} \mathrm{~Pb} /{ }^{238} \mathrm{U}$ ages of the three zircon grains (6-8) range from $238.0 \pm 4.0 \mathrm{Ma}$ (grain $8, n=$ 2) to $240 \pm 4 \mathrm{Ma}$ (grain $6, n=1$ ), with all six analyses yielding a weighted average ${ }^{206} \mathrm{~Pb} /{ }^{238} \mathrm{U}$ age of $238.6 \pm 1.5 \mathrm{Ma}(n=6)$, identical to a Concordia age of $238.4 \pm 1.9 \mathrm{Ma}\left(\mathrm{MSWD}_{\mathrm{C} .+\mathrm{E} .}=1.7\right.$, Probability $\mathrm{C} . \mathrm{E}_{\mathrm{E}}$ $=0.11, n=4)$ (Figure 5C). The five oldest grains $(1-5)$ show ${ }^{206} \mathrm{~Pb} /$ ${ }^{238} \mathrm{U}$ ages between $241 \pm 6$ (grain $5, n=1$ ) and $249.6 \pm 2.3 \mathrm{Ma}$ (grain $1, n=3$ ). Most of these grains are disturbed, as indicated by significant variations of their ${ }^{206} \mathrm{~Pb} /{ }^{238} \mathrm{U}$ ages, preventing calculation of single grain weighted average ${ }^{206} \mathrm{~Pb} /{ }^{238} \mathrm{U}$ ages (Figure 4).

\section{DISCUSSION}

\subsection{Triassic Zircon Grains in the Schilfsandstein}

The weighted mean ${ }^{206} \mathrm{~Pb} /{ }^{238} \mathrm{U}$ ages obtained during this study by multiple dating of nineteen zircon crystals range between $249.6 \pm$
2.3 $\mathrm{Ma}$ and $230.3 \pm 3.8 \mathrm{Ma}$, and provide the first hard evidence for the occurrence of Triassic zircon grains within the Stuttgart Formation. These ages in combination with the euhedral habitus of the analyzed zircon crystals suggest a volcanogenic origin. According to the Carnian depositional age of the Stuttgart Formation, these zircon grains are herein considered traces of pre- and syn-depositional tephra fall out related to Olenekian to late Carnian volcanic activity within the NW Tethys domain. This interpretation is in good agreement with the prevailing Northdirected wind regime of the northern summer monsoon proposed by Parrish (1999) for central Europe during the Triassic (Figure 1), and with $\mathrm{U}-\mathrm{Pb}$ ages between $242.01 \pm 0.05$ and $221.2 \pm 1.6 \mathrm{Ma}$ estimated for volcanic events in the NW Tethys domain (see Figures 1, 6). We note that the three weighted average ${ }^{206} \mathrm{~Pb} /{ }^{238} \mathrm{U}$ ages of $238.6 \pm 1.5 \mathrm{Ma}, 236.0 \pm 1.2 \mathrm{Ma}$, and $231.1 \pm 1.6 \mathrm{Ma}$ obtained during this study (Figure 4) overlap with the majority of zircon ages estimated for igneous rocks, tuffs and volcanogenic sandstones of the Transdanubian Range, southern Alps, N-Karawank Mountains, Drau Range, W Carpathians and Lagonegro Basin (for compilation and references see Figure 6). However, they are significantly older than $\mathrm{U}-\mathrm{Pb}$ ages of $211 \pm$ $3 \mathrm{Ma}$ and $222 \pm 2 \mathrm{Ma}$ (concordance level 90-110\%), recently dated by SHRIMP on zircon grains of the Lisowice bone-bearing horizon at Lipie Śląskie (Silesia, Poland) by Kowal-Linka et al. (2019). These young ages are interpreted to date tephra fall out around the Carnian/Norian boundary interval, which was probably related to volcanic sources in the West Carpathians (Figure 6), much younger than the Carnian volcanism being the source for the Schilfsandstein detrital zircons. Two older ages at $230 \pm 2 \mathrm{Ma}$ and $237 \pm 3 \mathrm{Ma}$, also reported by Kowal-Linka et al. (2019), provide evidence for the additional contribution of volcanic detritus related to late Ladinian to late Carnian volcanism. These two dates overlap those produced in this 

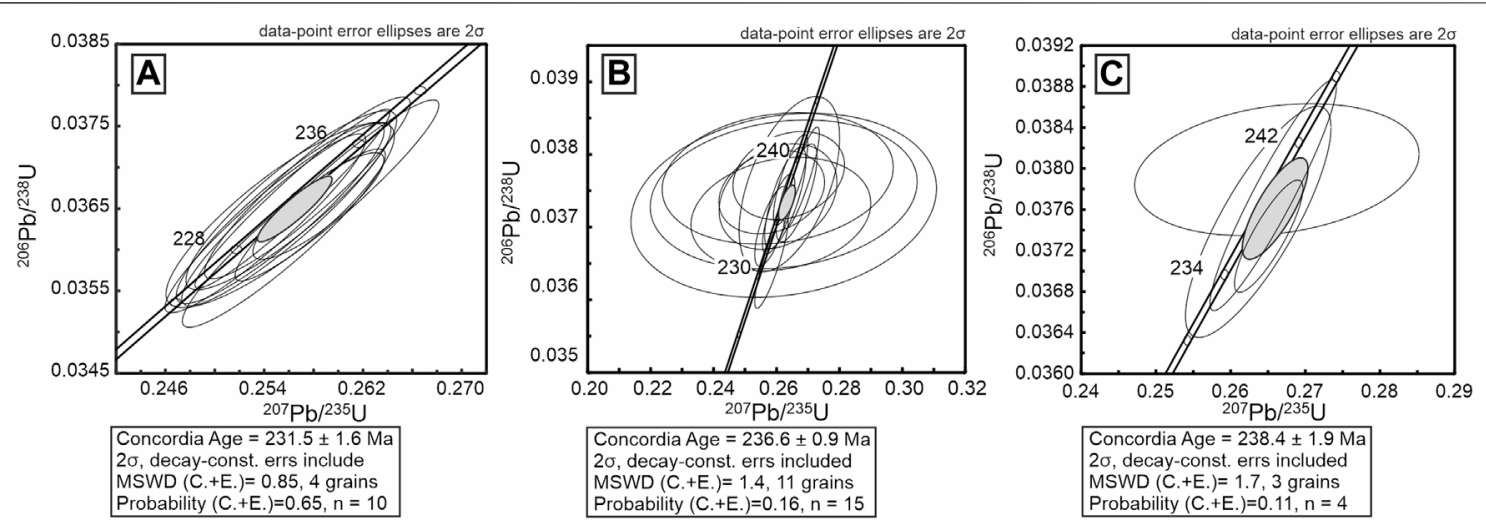

FIGURE 5 | Concordia diagrams showing the results of 29 analyses of the nineteen youngest zircon grains of sample Heilb-1 pooled in three clusters based on ${ }^{206} \mathrm{~Pb} /{ }^{238} \mathrm{U}$ ages. (A) results of multiple analyses of the four youngest zircon crystals (grains 16-19), (B) of the seven second oldest zircon grains (9-15), and (C) of the three oldest grains (6-8). MSWD, Mean squared weighted deviation, C.+E., concordance and equivalence.

study, and provide evidence that wide parts of the CEB were affected by Ladinian-Carnian tephra fall out, and that older volcanic detritus was re-deposited during late Carnian/early Norian sedimentation leading to formation of the Lisowice bone-bearing horizon. Evidence for tephra fall out during deposition of the Stuttgart Formation is, apart from the late Carnian age of $231.1 \pm 1.6 \mathrm{Ma}$ obtained from euhedral zircon grains, additionally provided by the occurrence of authigenic analcime, commonly considered to represent a diagenetic product of volcanic ashes (Hay, 1966; Füchtbauer, 1974; Kühn, 1976). Authigenic analcime cement occurs ubiquitously in sandstones of the Stuttgart Formation in North Germany as shown by Kühn (1976) and Förster et al. (2010), and more recently by Franz et al. (2018b) and Franz et al. (2019). However, it seems to be absent in South Germany (see Heling, 1965), as confirmed by the herein investigated sample from Heilbronn, in which analcime could not be found, neither by thin section survey nor XRD analyses. The reasons and consequences of this are discussed in Section 5.2.

The findings of Triassic zircon grains with ages between $249.6 \pm 2.3 \mathrm{Ma}$ and $230.3 \pm 3.8 \mathrm{Ma}$ provide evidence that the Stuttgart Formation contains traces of reworked tephra deposits of Olenekian to early Carnian age. We note that Hofmann et al. (2018) reported ten zircon crystals from Großmonra (Thuringia) showing ${ }^{206} \mathrm{~Pb} /{ }^{238} \mathrm{U}$ ages between $250 \pm 7$ and $234 \pm 7 \mathrm{Ma}(n=10)$ and two zircon crystals from Bodenmühle (Franconia) with ${ }^{206} \mathrm{~Pb} /{ }^{238} \mathrm{U}$ ages between $248 \pm 7$ and $247 \pm 7 \mathrm{Ma}(n=2)$, similar to the age spectrum reported herein (Figure 4). All these Triassic zircon grains were most probably incorporated into the Stuttgart Formation due to erosion of older Triassic strata in the southern CEB and at its margins.

Zircon grains which gave weighted average ${ }^{206} \mathrm{~Pb} /{ }^{238} \mathrm{U}$ ages of $236.0 \pm 1.2 \mathrm{Ma}$ and $238.6 \pm 1.5 \mathrm{Ma}$ suggest the presence of tephra deposits in the Grabfeld and Erfurt Formations of the Keuper Group (Figures 2, 6). As the Upper Grabfeld Formation is biostratigraphically constrained to the early Carnian (for details see Bachmann and Kozur, 2004), the erosion of early Carnian tephra with an age of $236.0 \pm 1.2$ Ma could be explained by fluvial incision of the Stuttgart Formation into the Upper Grabfeld Formation, which is well documented in South Germany (overview in Etzold and Schweizer in DSK (Deutsche Stratigraphische Kommission), 2005). But, as the fluvial incision of Schilfsandstein rivers in South Germany is limited to a few decametres (Etzold and Schweizer in DSK (Deutsche Stratigraphische Kommission), 2005), the erosion of late Ladinian tephra with an age of $238.6 \pm 1.5$ Ma must have been located at the southern margins of the CEB. The same interpretation can be applied to Triassic zircon grains of Olenekian to Anisian tephra. The fact that tephra deposits are unknown in Triassic strata of the CEB may be attributed to (fluvial) reworking after deposition, intense pedogenesis and modification due to diagenetic processes (see Section 5.2).

\subsection{Maximum Depositional Age of the Stuttgart Formation}

The four youngest zircon grains dated during this study yielded a weighted average ${ }^{206} \mathrm{~Pb} /{ }^{238} \mathrm{U}$ age of $231.1 \pm 1.6 \mathrm{Ma}$. These euhedral zircons are herein considered remnants of tephra, which was deposited in the active fluvial system of the Lower Schilfsandstein Member. After fall out in active channels, the tephra was mixed with detrital grains, dispersed downstream and stable tephra grains, such as zircon, became finally deposited within fluvial sands. At overbank environments, such as backswamps, wetlands and floodplains, distinct ash beds may have formed, but were disintegrated during the next flood stage or became finally preserved. The weighted average ${ }^{206} \mathrm{~Pb} /{ }^{238} \mathrm{U}$ age of $231.1 \pm 1.6 \mathrm{Ma}$ is identical, within error, with the two youngest zircon grains with ${ }^{206} \mathrm{~Pb} /{ }^{238} \mathrm{U}$ ages of $231 \pm 5 \mathrm{Ma}$ and $232 \pm 6 \mathrm{Ma}$ (concordance level 97-99\%), reported by Hofmann et al. (2018) from a sample of the Upper Schilfsandstein Member at Großmonra. This outcrop is located in Thuringia ca. $250 \mathrm{~km}$ northeast of Heilbronn (Figure 1). Even though not interpreted in detail by Hofmann et al. (2018), and unconfirmed by multiple zircon spot analyses, the presence of these zircon grains in Thuringia points to a wider distribution of syn-depositional 


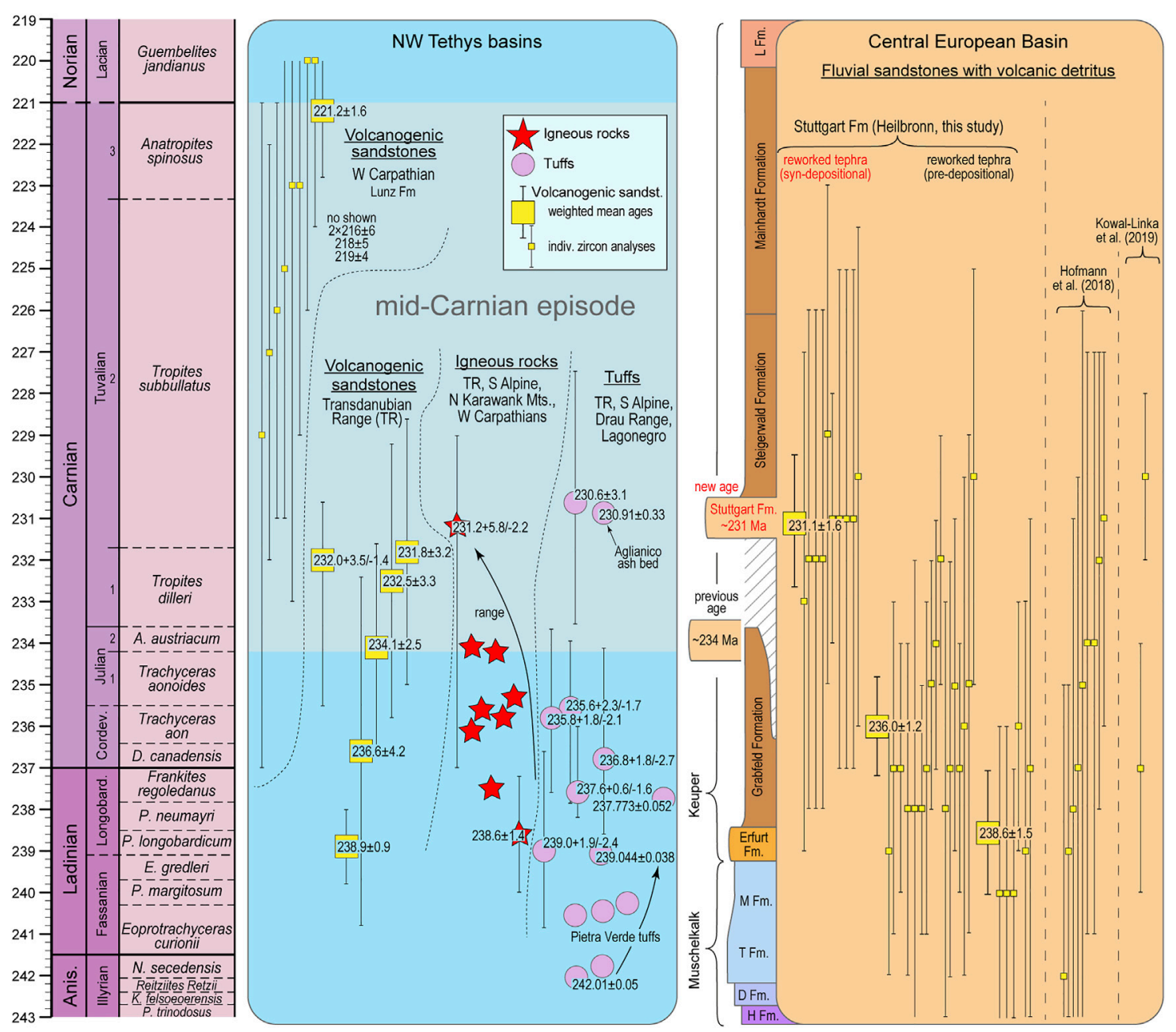

FIGURE 6 | Compilation of zircon U-Pb ages of igneous rocks, tuffs and volcanogenic sandstones of NW Tethys basins (published dates) compared with volcanic detritus found in fluvial sandstones of the Stuttgart Formation (this study; Hofmann et al., 2018) and the Upper Keuper (Kowal-Linka et al., 2019). Chronostratigraphy according to Zhang et al. (2020), base Norian at 221.0 Ma adopted from Kohut et al. (2018). Published dates were compiled from Furin et al. (2006), Mietto et al. (2012), Wotzlaw et al. (2018), Kohut et al. (2018), and Dunkl et al., 2019. The data presented herein suggest that detrital zircon grains in the Lower Schilfsandstein Member in SW Germany result from syn- and pre-depositional tephra fall out. Syn-depositional fall out occurred at $231.1 \pm 1.6 \mathrm{Ma}$ coeval to ash beds reported from the Lagonegro Basin (Furin et al., 2006) and the Transdanubian Range (Dunkl et al., 2019), and pre-depositional fall out mainly at $238.6 \pm 1.5 \mathrm{Ma}$ and $236.0 \pm 1.2 \mathrm{Ma}$ coeval to widespread Ladinian-early Carnian igneous activity in the NW Tethys. The occurrence of pre-depositional tephra within the Stuttgart Formation is explained by reworking of older ash beds, due to erosion of older strata and fluvial incision. Note, the stratigraphic column for the Central European Basin (right) shows the subdivision of the Upper Muschelkalk to Middle Keuper in the Heilbronn area located in the southern part of CEB, where the contact of the Stuttgart Formation to the underlying Grabfeld Formation is discontinuous (see Figure 2): H Fm., Heilbronn-Formation; D Fm., Diemel Formation; T Fm., Trochitenkalk Formation; M Fm., Meissner Formation; L Fm., Löwenstein Formation. Further shown is the previously suggested age for the Stuttgart Formation, based on bio-magneto-sequence stratigraphic record (Zhang et al., 2020).

tephra in the Stuttgart Formation. Considering this and the short time-span of 0.8-1.2 Ma estimated for the Stuttgart Formation (Kozur and Bachmann, 2010; Miller et al., 2017), the weighted average ${ }^{206} \mathrm{~Pb} /{ }^{238} \mathrm{U}$ age of $231.1 \pm 1.6 \mathrm{Ma}$ is taken as the best current estimate for the maximum depositional age (e.g., Rainbird et al., 2001; Brown and Gehrels, 2007) of the Stuttgart Formation in South Germany.

Syn-depositional tephra fall out is supported by the occurrence of authigenic analcime cement in the Stuttgart Formation, representing the diagenetic product of volcanic ash (Kühn, 1976; Förster et al., 2010; Franz et al., 2018b; Franz et al.
(2019)). But the ubiquitous presence of analcime in the northern CEB, it's absence in the southern CEB, and the fact that ash beds have not been observed in the Stuttgart Formation needs to be explained. As the diagenetic stability of detrital minerals is mainly a function of pore-water chemistry, depositional environments directly impact diagenetic pathways of volcanic detritus in sediments (Hay, 1966; Hurst and Irwin, 1982; Burley et al., 1985). As shown by Hay (1966), the presence of moderate saline depositional water leads to authigenesis of analcime during diagenetic alteration of volcanic ash, whereas interaction with meteoric (freshwater) depositional water leads to 
authigenesis of montmorillonite. This is in congruence with the palaeogeographic situation and authigenic mineralogy of the Stuttgart Formation. The present-day occurrence of authigenic analcime in the northern CEB corresponds to the extension of the marine-brackish inland sea (Kühn, 1976; Förster et al., 2010; Franz et al., 2018b) and its absence in the southern CEB (Heling, 1965; Kühn, 1976; Nürnberger, 2010) corresponds to the presence of fluvial environments in this part of the basin (Figure 2). However, montmorillonite was only reported from a single locality at the southern margin of the CEB, where it occurs at a very low abundance (Salger, 1982). The apparent absence is most probably related to illitization of montmorillonite, a common mesodiagenetic dehydration reaction associated to burial temperatures between 50 and $135^{\circ} \mathrm{C}$ (e.g., Patrick Muffler and White, 1969; De Segonzac, 1970; Perry and Hower, 1970; Dypvik, 1983). This is in general agreement with the dominance of illite in clay mineral assemblages of the Stuttgart Formation in the southern CEB (Heling, 1965; Dockter and Kühn, 1974; Häusser and Kurze, 1975; Salger, 1982) and maximum burial temperatures of up to $100^{\circ} \mathrm{C}$ estimated for the Keuper Group in Thuringia (Voigt et al., 2010; Beyer, 2015).

Intense burial diagenesis at depths of $>2,000 \mathrm{~m}$, in particular in the northern $\mathrm{CEB}$, and related maximum burial temperatures of $>100^{\circ} \mathrm{C}$ (e.g., Neunzert et al., 1996; Hoth, 1997; Thomson and Zeh, 2000; Friberg, 2001; Rodon and Littke, 2005), may explain why ash beds were not observed within fine-grained successions of the Stuttgart Formation so far. As described from Mesozoic strata elsewhere in the $\mathrm{CEB}$, fine-grained ash underwent argillization during early diagenesis before cementation could preserve typical textures (Jeans et al., 2000). Further modifications during burial diagenesis, i.e., the alteration of volcanic glass and transitions of clay minerals (e.g., Segonzac, 1970; Cuadros et al., 2013; Gong et al., 2018), contribute to the obliteration of volcanic minerals and overprint of typical textures.

\subsection{Correlation and Timing of the Mid-Carnian Episode}

The new weighted average ${ }^{206} \mathrm{~Pb} /{ }^{238} \mathrm{U}$ age of $231.1 \pm 1.6 \mathrm{Ma}$ constrains the Stuttgart Formation to the Tuvalian two substage of the Carnian (Figure 6). Accepting this new age as maximum depositional age, the Stuttgart Formation is c. 3 myr younger compared to the age of about $234 \mathrm{Ma}$ as proposed by Zhang et al. (2020). Noteworthy, the depositional age of Zhang et al. (2020), obtained from the correlation with the Global Polarity Time Scale, relies on a rather preliminary biostratigraphic correlation of the Stuttgart Formation with Tethyan strata (see Section 2.2).

We note that the new maximum depositional age of the Stuttgart Formation overlaps, within error, with the highprecision ${ }^{206} \mathrm{~Pb} /{ }^{238} \mathrm{U}$ TIMS age of $230.91 \pm 0.33 \mathrm{Ma}$ reported by Furin et al. (2006) for the Aglianico ash bed (Lagonegro Basin, southern Italy), which is biostratigraphically constrained to the Tuvalian two substage. It further overlaps with Concordia ages of $232.5 \pm 3.3$ and $230.6 \pm 3.1$ Ma reported by Dunkl et al. (2019) from pebbles of reworked tuffs and volcanogenic sandstones of the Transdanubian Range in Hungary (Figure 6). Whether these records are related to a phase of volcanic activity or if they can be attributed to a single volcanic event has to be verified by further investigations, including the application of high precision dating techniques.

Since the Schilfsandstein (Stuttgart Formation) represents the type-example of the mid-Carnian episode (Simms and Ruffell, 1989), the new maximum depositional age has significant impact on the timing of the mid-Carnian episode. The correlation of the Stuttgart Formation with the Aglianico ash bed, biostratigraphically dated as Tuvalian 2 (Furin et al., 2006), and contemporaneous strata of NW Tethyan basins, contradicts a synchronous onset of the mid-Carnian episode in the late Julian at around $234 \mathrm{Ma}$ as reconstructed previously (e.g., Simms and Ruffell, 1989; Hornung et al., 2007a,; Hornung et al., 2007b; Roghi et al., 2010; Franz et al., 2014; Dal Corso et al., 2015, Dal Corso et al., 2020; Jin et al., 2020; Li et al., 2020; Mancuso et al., 2020). The new depositional age of the Stuttgart Formation indicates that the onset of the mid-Carnian episode in the CEB was delayed by about 3 myr compared to basins of the NW Tethys domain. If this is also the case for other basins of the peri-Tethyan realm, such as the Paris Basin or the Iberian Basins, needs to be verified by further investigations.

The end of the mid-Carnian episode ranges from the late Julian 2 in the Transdanubian Range (Dal Corso et al., 2015) to the early Tuvalian 2 in the Southern Alps and other basins (Dal Corso et al., 2018; Dal Corso et al., 2020). But the recently reported maximum depositional age of $221.2 \pm 1.6 \mathrm{Ma}$ for the top of the Lunz Formation in the western Carpathians (Kohut et al., 2018) points to a much longer range of clastic input in this part of the Tethys (Figure 6). Considering the lower limit at $234 \mathrm{Ma}$ and accepting the upper limit of the mid-Carnian episode at c. $221 \mathrm{Ma}$, as proposed by Kohut et al. (2018), results in a maximum duration of about 13 myr; the multiple of 1.5-1.7 myr as previously reconstructed by Bernardi et al. (2018) and Li et al. (2020).

\section{CONCLUSION}

Multiple LA-ICP-MS spot analyses of euhedral zircon grains, recovered from the Schilfsandstein (Stuttgart Formation) at Heilbronn (SW Germany), provide the first robust evidence of Triassic tephra fallout in the Central European Basin. The following conclusions can be drawn from this reconnaissance study.

1) The presence of volcanic zircon grains with ${ }^{206} \mathrm{~Pb} /{ }^{238} \mathrm{U}$ ages between $250 \pm 3 \mathrm{Ma}$ and $230 \pm 4 \mathrm{Ma}$ evidences repeated tephra fallout from the Olenekian to late Carnian in the Central European Basin.

2) Representing detritus of dispersed syn-depositional tephra, the four youngest zircon grains of euhedral habitus gave a weighted average ${ }^{206} \mathrm{~Pb} /{ }^{238} \mathrm{U}$ age of $231.1 \pm 1.6 \mathrm{Ma}(10$ analyses). This new maximum depositional age of the Stuttgart Formation is about 3 myr younger than previously suggested.

3) The late Carnian volcanic zircon grains from Heilbronn, but also the volcanic zircon grains with ${ }^{206} \mathrm{~Pb} /{ }^{238} \mathrm{U}$ ages of $231 \pm$ 
$5 \mathrm{Ma}$ and $232 \pm 6 \mathrm{Ma}$ from Großmonra/Thuringia, and the ubiquitous presence of authigenic analcime reveals a wider distribution of syn-depositional tephra in the Stuttgart Formation.

4) The new maximum depositional age of the Stuttgart Formation indicates that the onset of the mid-Carnian episode in the Central European Basin occurred about 3 myr later than compared to basins of the NW Tethys domain.

5) The finding of volcanic zircon grains of Olenekian to early Carnian age in the Stuttgart Formation points to the presence of tephra beds in the Buntsandstein to Keuper Groups, which were previously overlooked. The detritus of these predepositional tephra beds was incorporated into the Stuttgart Formation due to fluvial incision and reworking at the southern margins of the Central European Basin.

6) The congruence of herein reported ${ }^{206} \mathrm{~Pb} /{ }^{238} \mathrm{U}$ ages of volcanic zircons with published ${ }^{206} \mathrm{~Pb} /{ }^{238} \mathrm{U}$ ages of tephra beds and volcanogenic sandstones from Tethyan basins suggest a common source in the NW Tethys domain and transport of tephra to the Central European Basin by monsoonal circulation systems.

\section{REFERENCES}

Aigner, T., and Bachmann, G. H. (1992). Sequence-stratigraphic Framework of the German Triassic. Sediment. Geology 80, 115-135. doi:10.1016/0037-0738(92) 90035-p

Arche, A., and López-Gómez, J. (2014). The Carnian Pluvial Event in Western Europe: New Data from Iberia and Correlation with the Western Neotethys and Eastern North America-NW Africa Regions. Earth-Science Rev. 128, 196-231. doi:10.1016/j.earscirev.2013.10.012

Bachmann, G. H., Beutler, G., Hagdorn, H., and Hauschke, N. (1999). "Stratigraphie der Germanischen Trias," in Trias - eine ganz andere Welt. Editors N. Hauschke and V. Wilde (München: Pfeil), 81-104.

Bachmann, G. H., Geluk, M. C., Warrington, G., Becker-Roman, A., Beutler, G., Hagdorn, H., et al. (2010). "Triassic," in Petroleum Geological Atlas of the Southern Permian Basin Area. Editors J. C. Doornenbal and A. G. Stevenson (Houten: EAGE Publication), 149-173.

Bachmann, G. H., and Kozur, H. (2004). The Germanic Triassic: Correlations with the International Chronostratigraphic Scale, Numerical Ages and Milankovitch Cyclicity. Hallesches Jahrbuch für Geowissenschaften B. 26, 17-62.

Bachmann, G. H., and Wild, H. (1976). Die Grenze Gipskeuper/Schilfsandstein (Mittlerer Keuper) bei Heilbronn/Neckar. Jahresberichte des Oberrheinischen geologischen Vereins, N. F. 58, 137-152. doi:10.1127/jmogv/58/1976/137

Barnasch, J. (2010). Der Keuper im Westteil des Zentraleuropäischen Beckens (Deutschland, Niederlande, England, Dänemark): diskontinuierliche Sedimentation, Litho-, Zyklo- und Sequenzstratigraphie. Schriftenreihe der Deutschen Gesellschaft für Geowissenschaften 71, 170. doi:10.1127/sdgg/71/ 2010/7

Beltrán-Triviño, A., Winkler, W., von Quadt, A., and Gallhofer, D. (2016). Triassic Magmatism on the Transition from Variscan to Alpine Cycles: Evidence from U-Pb, Hf, and Geochemistry of Detrital Minerals. Swiss J. Geosci. 109, 309-328. doi:10.1007/s00015-016-0234-3

Bernardi, M., Gianolla, P., Petti, F. M., Mietto, P., and Benton, M. J. (2018). Dinosaur Diversification Linked with the Carnian Pluvial Episode. Nat. Commun. 9, 1-10. doi:10.1038/s41467-018-03996-1

Beutler, G., and Häusser, I. (1982). Über den Schilfsandstein der DDR. Z. für Geologische Wissenschaften 10, 511-525.

Beutler, G. (1995). Quantifizierung der altkimmerischen Bewegungen in Nordwestdeutschland. Ber. Archiv-nr. 113087, 1-147. Hannover (Bundesanstalt für Geowissenschaften und Rohstoffe).

\section{DATA AVAILABILITY STATEMENT}

The original contributions presented in the study are included in the article/Supplementary Material, further inquiries can be directed to the corresponding author.

\section{AUTHOR CONTRIBUTIONS}

$\mathrm{AZ}$ did sampling, zircon separation, $\mathrm{U}-\mathrm{Pb}$ dating and data processing, BSE-imaging. MF and $\mathrm{KO}$ compiled literature data and produced half of the figures. AZ and MF wrote the first draft of the manuscript. All authors contributed to manuscript revision, read, and approved the submitted version.

\section{SUPPLEMENTARY MATERIAL}

The Supplementary Material for this article can be found online at: https://www.frontiersin.org/articles/10.3389/feart.2021.778820/ full\#supplementary-material

Beyer, D. (2015). Evolution of Reservoir Properties in the Lower Triassic Aquifer Sandstones of the Thuringian Syncline in Central Germany. Disseration thesis. Friedrich-Schiller-Universität Jena, 124. Available at: https://www.dbthueringen.de/servlets/MCRFileNodeServlet/dbt_derivate_00031526/Diss/ Dissertation\%20Beyer.pdf.

Bianchini, G., Natali, C., Shibata, T., and Yoshikawa, M. (2018). Basic Dykes Crosscutting the Crystalline Basement of Valsugana (Italy): New Evidence of Early Triassic Volcanism in the Southern Alps. Tectonics 37, 2080-2093. doi:10.1029/2017tc004950

Brown, E. H., and Gehrels, G. E. (2007). Detrital Zircon Constraints on Terrane Ages and Affinities and Timing of Orogenic Events in the San Juan Islands and North Cascades, Washington. Can. J. Earth Sci. 44, 1375-1396. doi:10.1139/ e07-040

Brusca, C., Gaetani, M., Jadoul, F., and Viel, G. (1982). Paleogeografia LadinoCarnica e metallogenesi nel Sudalpino. Mem. Soc. Geol. It. 22, 65-82.

Burley, S. D., Kantorowicz, J. D., and Waugh, B. (1985). Clastic Diagenesis. Geological Society, London, Special Publications, 189-226. doi:10.1144/ gsl.sp.1985.018.01.10

Cassinis, G., Cortesogno, L., Gaggero, L., Perotti, C. R., and Buzzi, L. (2008). Permian to Triassic Geodynamic and Magmatic Evolution of the Brescian Prealps (Eastern Lombardy, Italy). Boll. Soc. Geol. It. 127, 501-518.

Cuadros, J., Afsin, B., Jadubansa, P., Ardakani, M., Ascaso, C., and Wierzchos, J. (2013). Pathways of Volcanic Glass Alteration in Laboratory Experiments through Inorganic and Microbially-Mediated Processes. Clay Miner. 48, 423-445. doi:10.1180/claymin.2013.048.3.01

Dal Corso, J., Bernardi, M., Sun, Y., Song, H., Seyfullah, L. J., Preto, N., et al. (2020). Extinction and Dawn of the Modern World in the Carnian (Late Triassic). Sci. $A d v$. 6, eaba0099. doi:10.1126/sciadv.aba0099

Dal Corso, J., Gianolla, P., Newton, R. J., Franceschi, M., Roghi, G., Caggiati, M., et al. (2015). Carbon Isotope Records Reveal Synchronicity between Carbon Cycle Perturbation and the "Carnian Pluvial Event" in the Tethys Realm (Late Triassic). Glob. Planet. Change 127, 79-90. doi:10.1016/j.gloplacha.2015.01.013

Dal Corso, J., Gianolla, P., Rigo, M., Franceschi, M., Roghi, G., Mietto, P., et al. (2018). Multiple Negative Carbon-Isotope Excursions during the Carnian Pluvial Episode (Late Triassic). Earth-Science Rev. 185, 732-750. doi:10.1016/j.earscirev.2018.07.004

Dal Corso, J., Mietto, P., Newton, R. J., Pancost, R. D., Preto, N., Roghi, G., et al. (2012). Discovery of a Major Negative $\delta^{13} \mathrm{C}$ Spike in the Carnian (Late Triassic) Linked to the Eruption of Wrangellia Flood Basalts. Geology 40, 79-82. doi:10.1130/g32473.1 
De Min, A., Velicogna, M., Ziberna, L., Chiaradia, M., Alberti, A., and Marzoli, A. (2020). Triassic Magmatism in the European Southern Alps as an Early Phase of Pangea Break-Up. Geol. Mag. 157, 1800-1822. doi:10.1017/s0016756820000084

Dockter, J., and Kühn, W. (1974). "Fazies und Sedimentologie des Keupers im Thüringer Becken," in Sedimentäre Fazies - Fortschritte der Sedimentationsanalyse; Exkursionsf. Tagg. Gesellsch. geol. Wiss. DDR vom 16.-18. Mai 1974 in Gera. Berlin, 48-59.

DSK (Deutsche Stratigraphische Kommission) (2005). "Stratigraphie von Deutschland, IV: Keuper," in Courier Forschungsinstitut Senckenberg. Schweizerbart Science Publishers, 253, 296.

DSK (Deutsche Stratigraphische Kommission) (2013). "Stratigraphie von Deutschland, XI: Buntsandstein," in Schriftenreihe der Deutschen Gesellschaft für Geowissenschaften, 69, 657.

DSK (Deutsche Stratigraphische Kommission) (2020). "Stratigraphie von Deutschland, XIII: Muschelkalk," in Schriftenreihe der Deutschen Gesellschaft für Geowissenschaften, 91, 1256.

Dunkl, I., Farics, É., Józsa, S., Lukács, R., Haas, J., and Budai, T. (2019). Traces of Carnian Volcanic Activity in the Transdanubian Range, Hungary. Int. J. Earth Sci. (Geol Rundsch) 108, 1451-1466. doi:10.1007/s00531-019-01714-w

Dypvik, H. (1983). Clay mineral Transformations in Tertiary and Mesozoic Sediments from North Sea. Bull. Am. Ass. Petrol. Geol. 67, 160-165. doi:10.1306/03b5acdc-16d1-11d7-8645000102c1865d

Feist-Burkhardt, S., Götz, A. E., Szulc, J., Borkhataria, R., Geluk, M., Haas, J., et al. (2008). "Triassic," in The Geology of Central Europe: Mesozoic and Cenozoic. Editor A. McCann (London: Geological Society of London), 749-821.

Fisher, M. J., and Mudge, D. C. (1990). "Triassic," in Introduction to the Petroleum Geology of the North Sea. Editor K.W. Glennie (Oxford: Blackwell), 191-218.

Förster, A., Schöner, R., Förster, H.-J., Norden, B., Blaschke, A.-W., Luckert, J., et al. (2010). Reservoir Characterization of a CO2 Storage Aquifer: The Upper Triassic Stuttgart Formation in the Northeast German Basin. Mar. Pet. Geology. 27, 2156-2172. doi:10.1016/j.marpetgeo.2010.07.010

Franz, M., Bachmann, G. H., Barnasch, J., Heunisch, C., and Röhling, H.-G. (2018a). Der Keuper in der Stratigraphischen Tabelle von Deutschland 2016 kontinuierliche Sedimentation in der norddeutschen Beckenfazies (Variante B). Zeitschrift der Deutschen Gesellschaft für Geowissenschaften 169, 203-224. doi:10.1127/zdgg/2018/0114

Franz, M., and Barnasch, J. (2021). "Der Keuper im zentralen Germanischen Becken," in Trias - Aufbruch in das Erdmittelalter. Editors N. Hauschke, M. Franz, and G. H. Bachmann (München: Pfeil), 83-108.

Franz, M., Kustatscher, E., Heunisch, C., Niegel, S., and Röhling, H.-G. (2019). The Schilfsandstein and its flora; Arguments for a Humid Mid-carnian Episode? J. Geol. Soc. 176, 133-148. doi:10.1144/jgs2018-053

Franz, M. (2008). Litho- und Leitflächenstratigraphie, Chronostratigraphie, Zyklound Sequenzstratigraphie des Keupers im östlichen Zentraleuropäischen Becken (Deutschland, Polen) und Dänischen Becken (Dänemark, Schweden). Ph.D. Thesis. Germany: Martin-Luther-Universität HalleWittenberg, 198. Available at: http://sundoc.bibliothek.uni-halle.de/dissonline/08/09H048/index.htm.

Franz, M., Nowak, K., Berner, U., Heunisch, C., Bandel, K., Röhling, H.-G., et al. (2014). Eustatic Control on Epicontinental Basins: the Example of the Stuttgart Formation in the Central European Basin (Middle Keuper, Late Triassic). Glob. Planet. Change 122, 305-329. doi:10.1016/ j.gloplacha.2014.07.010

Franz, M., Nowak, K., Niegel, S., Seidel, E., Wolf, M., and Wolfgramm, M. (2018b). Deep Geothermal Resources of the North German Basin: The Hydrothermal Reservoirs of the Stuttgart Formation (Schilfsandstein, Upper Triassic). Zeitschrift der Deutschen Gesellschaft für Geowissenschaften 169, 353-387. doi:10.1127/zdgg/2018/0164

Friberg, L. J. (2001). Untersuchungen zur Temperatur- und Absenkungsgeschichte sowie zur Bildung und Migration von Methan und molekularem Stickstoff im Nordostdeutschen Becken. Berichte Forschungszentrum Jülich 3914, 226.

Füchtbauer, H. (1974). Zur Diagenese Fluviatiler Sedimente. Geologische Rundschau 63, 904-925.

Furin, S., Preto, N., Rigo, M., Roghi, G., Gianolla, P., Crowley, J. L., et al. (2006). High-precision U-Pb Zircon Age from the Triassic of Italy: Implications for the Triassic Time Scale and the Carnian Origin of Calcareous Nannoplankton and Dinosaurs. Geol 34, 1009-1012. doi:10.1130/g22967a.1
Garzanti, E. (1985). The sandstone Memory of the Evolution of a Triassic Volcanic Arc in the Southern Alps, Italy. Sedimentology 32, 423-433. doi:10.1111/j.13653091.1985.tb00521.x

Gerdes, A., and Zeh, A. (2006). Combined U-Pb and Hf Isotope LA-(MC-)ICP-MS Analyses of Detrital Zircons: Comparison with SHRIMP and New Constraints for the Provenance and Age of an Armorican Metasediment in Central Germany. Earth Planet. Sci. Lett. 249, 47-61. doi:10.1016/j.epsl.2006.06.039

Gerdes, A., and Zeh, A. (2009). Zircon Formation versus Zircon Alteration - New Insights from Combined U-Pb and Lu-Hf In-Situ LA-ICP-MS Analyses, and Consequences for the Interpretation of Archean Zircon from the Central Zone of the Limpopo Belt. Chem. Geology. 261, 230-243. doi:10.1016/ j.chemgeo.2008.03.005

Geyer, G., and Kelber, K.-P. (2018). Spinicaudata ("Conchostraca," Crustacea) from the Middle Keuper (Upper Triassic) of the Southern Germanic Basin, with a Review of Carnian-Norian Taxa and Suggested Biozones. PalZ 92, 1-34. doi:10.1007/s12542-017-0363-7

Gong, N., Hong, H., Huff, W. D., Fang, Q., Bae, C. J., Wang, C., et al. (2018). Influences of Sedimentary Environments and Volcanic Sources on Diagenetic Alteration of Volcanic Tuffs in South China. Sci. Rep. 8, 7616. doi:10.1038/ s41598-018-26044-w

Häusser, I., and Kurze, M. (1975). Sedimentationsbedingungen und Schwermineralführung im Mesozoikum des Nordteils der DDR. Z. Geol. Wiss. 3, 1317-1332.

Hay, R. L. (1966). Zeolites and Zeolitic Reactions in Sedimentary Rocks, 85. Geological Society of America, Special Paper, 180.

Heling, D. (1965). Zur Petrographie des Schilfsandsteins. Beitr Mineral. u Petrogr 11, 272-296. doi:10.1007/bf01172137

Heunisch, C. (1999). "Die Bedeutung der Palynologie für Biostratigraphie und Fazies in der Germanischen Trias," in Trias: eine ganz andere Welt. Editors N. Hauschke and V. Wilde (München: Pfeil), 207-220.

Heunisch, C., and Wierer, F. (2021). "Palynomorphe der Germanischen Trias," in Trias - Aufbruch in das Erdmittelalter. Editors N. Hauschke, M. Franz, and G. H. Bachmann (München: Pfeil), 205-217.

Hiess, J., Condon, D. J., McLean, N., and Noble, S. R. (2012). ${ }^{238} \mathrm{U} /{ }^{235} \mathrm{U}$ Systematics in Terrestrial Uranium-Bearing Minerals. Science 335, 1610-1614. doi:10.1126/ science. 1215507

Hofmann, M., Voigt, T., Bittner, L., Gärtner, A., Zieger, J., and Linnemann, U. (2018). Reworked Middle Jurassic Sandstones as a Marker for Upper Cretaceous basin Inversion in Central Europe-A Case Study for the U-Pb Detrital Zircon Record of the Upper Cretaceous Schmilka Section and Their Implication for the Sedimentary Cover of the Lausitz Block (Saxony, Germany). Int. J. Earth Sci. (Geol Rundsch) 107, 913-932. doi:10.1007/s00531-017-1552-z

Hornung, T., Brandner, R., Krystyn, L., Joachimski, M. M., and Keim, L. (2007a). Multistratigraphic Constraints on the NW Tethyan "Carnian Crisis". New Mexico Mus. Nat. Hist. Bulletins 4, 9-67.

Hornung, T., Krystyn, L., and Brandner, R. (2007b). A Tethys-wide Mid-carnian (Upper Triassic) Carbonate Productivity Crisis: Evidence for the Alpine Reingraben Event from Spiti (Indian Himalaya)? J. Asian Earth Sci. 30, 285-302. doi:10.1016/j.jseaes.2006.10.001

Hoth, P. (1997). Fazies und Diagenese von Präperm-Sedimenten der Geotraverse Harz - Rügen. Schriftenreihe für Geowissenschaften. Ostklüne: Verlag Störr $4,139$.

Hurst, A., and Irwin, H. (1982). Geological Modelling of clay Diagenesis in Sandstones. Clay Miner. 17, 5-22. doi:10.1180/claymin.1982.017.1.03

Jackson, S. E., Pearson, N. J., Griffin, W. L., and Belousova, E. A. (2004). The Application of Laser Ablation-Inductively Coupled Plasma-Mass Spectrometry to In Situ U-Pb Zircon Geochronology. Chem. Geology. 211, 47-69. doi:10.1016/j.chemgeo.2004.06.017

Jäger, F. (1827). Über Pflanzenversteinerungen welche in dem Bausandstein von Stuttgart vorkommen. Stuttgart: Metzler, 40.

Jeans, C. V., Wray, D. S., Merriman, R. J., and Fisher, M. J. (2000). Volcanogenic Clays in Jurassic and Cretaceous Strata of England and the North Sea Basin. Clay Miner. 35, 25-55. doi:10.1180/000985500546710

Jin, X., Gianolla, P., Shi, Z., Franceschi, M., Caggiati, M., Du, Y., et al. (2020). Synchronized Changes in Shallow Water Carbonate Production during the Carnian Pluvial Episode (Late Triassic) throughout Tethys. Glob. Planet. Change 184, 103035. doi:10.1016/j.gloplacha.2019.103035 
Kendall, G. C. S. C., Lake, P., Weathers, H. D., III, Lakshmi, V., Althausen, J., and Alsharan, A. S. (2003). "Evidence of Rain Shadow in the Geologic Record: Repeated Evaporite Accumulation at Extensional and Compressional Plate Margins," in Desertification in the Third Millennium. Editors A.S. Alsharan, W.W.A.S. WoodGoudie, A. Fowler, and E.M. Abdellatif (Netherlands: Swets \& Zeitlinger), 45-52.

Kohút, M., Hofmann, M., Havrila, M., Linnemann, U., and Havrila, J. (2018). Tracking an Upper Limit of the "Carnian Crisis" And/or Carnian Stage in the Western Carpathians (Slovakia). Int. J. Earth Sci. (Geol. Rundsch) 107, 321-335. doi:10.1007/s00531-017-1491-8

Kowal-Linka, M., Krzemińska, E., and Czupyt, Z. (2019). The Youngest Detrital Zircons from the Upper Triassic Lipie Śląskie (Lisowice) continental Deposits (Poland): Implications for the Maximum Depositional Age of the Lisowice Bone-Bearing Horizon. Palaeogeogr. Palaeoclimatol. Palaeoecol. 514, 487-501. doi:10.1016/j.palaeo.2018.11.012

Kozur, H. W., and Bachmann, G. H. (2010). The Middle Carnian Wet Intermezzo of the Stuttgart Formation (Schilfsandstein), Germanic Basin. Palaeogeogr. Palaeoclimatol. Palaeoecol. 290, 107-119. doi:10.1016/j.palaeo.2009.11.004

Kozur, H. W., and Weems, R. E. (2010). "The Biostratigraphic Importance of Conchostracans in the continental Triassic of the Northern Hemisphere," in The Triassic Timescale. Editor S. G. Lucas (Geol. Soc. London, Special Pub), 334, 315-417. doi:10.1144/sp334.13

Kozur, H. W., and Weems, R. E. (2007). "Upper Triassic Conchostracan Biostratigraphy of the continental Rift Basins of Eastern North America: its Importance for Correlating Newark Supergroup Events with the German Basin and the International Geological Time Scale," in The Global Triassic. Editors S. G. Lucas and J. A. Spielmann (New Mexico: Museum of Natural History \& Science Bulletins), 41, 137-188.

Kühn, W. (1976). Einige Bemerkungen zum Auftreten von Analcim im Keuper. Jahrbuch für Geologie. 5/6 (1969/1970), 269-276.

Kutzbach, J. E., and Gallimore, R. G. (1989). Pangaean Climates: Megamonsoons of the Megacontinent. J. Geophys. Res. 94 (D3), 3341-3357. doi:10.1029/ jd094id03p03341

Larsen, B. T., Olaussen, S., Sundvoll, B., and Heeremans, M. (2008). The PermoCarboniferous Oslo Rift through Six Stages and 65 Million Years. Episodes 31, 52-58. doi:10.18814/epiiugs/2008/v31i1/008

Li, Z., Chen, Z.-Q., Zhang, F., Ogg, J. G., and Zhao, L. (2020). Global Carbon Cycle Perturbations Triggered by Volatile Volcanism and Ecosystem Responses during the Carnian Pluvial Episode (Late Triassic). Earth-Science Rev. 211, 103404. doi:10.1016/j.earscirev.2020.103404

López-Gómez, J., Escudero-Mozo, M. J., Martín-Chivelet, J., Arche, A., Lago, M., and Galé, C. (2017). Western Tethys continental-marine Responses to the Carnian Humid Episode: Palaeoclimatic and Palaeogeographic Implications. Glob. Planet. Change 148, 79-95. doi:10.1016/j.gloplacha.2016.11.016

Lu, J., Zhang, P., Dal Corso, J., Yang, M., Wignall, P. B., Greene, S. E., et al. (2021). Volcanically Driven Lacustrine Ecosystem Changes during the Carnian Pluvial Episode (Late Triassic). Proc. Natl. Acad. Sci. USA 118, e2109895118. doi:10.1073/pnas.2109895118

Ludwig, K. (2001). "Isoplot/Ex, Rev. 2.49," in A Geochronological Toolkit for Microsoft Excel (Berkeley Geochronology Center, Special Publication No. 1a).

Lustrino, M., Abbas, H., Agostini, S., Caggiati, M., Carminati, E., and Gianolla, P. (2019). Origin of Triassic Magmatism of the Southern Alps (Italy): Constraints from Geochemistry and Sr-Nd-Pb Isotopic Ratios. Gondwana Res. 75, 218-238. doi:10.1016/j.gr.2019.04.011

Mancuso, A. C., Benavente, C. A., Irmis, R. B., and Mundil, R. (2020). Evidence for the Carnian Pluvial Episode in Gondwana: New Multiproxy Climate Records and Their Bearing on Early dinosaur Diversification. Gondwana Res. 86, 104-125. doi:10.1016/j.gr.2020.05.009

Marocchi, M., Morelli, C., Mair, V., Klötzli, U., and Bargossi, G. M. (2008). Evolution of Large Silicic Magma Systems: New U-Pb Zircon Data on the NW Permian Athesian Volcanic Group (Southern Alps, Italy). J. Geology. 116, 480-498. doi:10.1086/590135

Maury, R. C., Lapierre, H., Bosch, D., Marcoux, J., Krystyn, L., Cotten, J., et al. (2008). The Alkaline Intraplate Volcanism of the Antalya Nappes (Turkey): a Late Triassic Remnant of the Neotethys. Bull. Soc. Géol. Fr. 179, 397-410. doi:10.2113/gssgfbull.179.4.397

McKie, T. (2017). "Paleogeographic Evolution of Latest Permian and Triassic Salt Basins in Northwest Europe," in Permo-Triassic Salt Provinces of Europe, North
Africa and the Atlantic Margins - Tectonics and Hydrocarbon Potential. Editors J.I. Soto, J.F. Flinch, and G. Tari (Elsevier), 159-173. doi:10.1016/b978-0-12809417-4.00008-2

Mietto, P., Manfrin, S., Preto, N., Rigo, M., Roghi, G., Furin, S., et al. (2012). The Global Boundary Stratotype Section and Point (GSSP) of the Carnian stage (Late Triassic) at Prati di Stuores/Stuores Wiesen section (Southern Alps, NE Italy). Episodes 35, 414-430. doi:10.18814/epiiugs/2012/v35i3/003

Miller, C. S., Peterse, F., da Silva, A.-C., Baranyi, V., Reichart, G. J., and Kürschner, W. M. (2017). Astronomical Age Constraints and Extinction Mechanisms of the Late Triassic Carnian Crisis. Sci. Rep. 7, 2557. doi:10.1038/s41598-017$02817-7$

Moix, P., Vachard, D., Allibon, J., Martini, R., Wernli, R., Kozur, H. W., et al. (2013). "Paleotethyan, Neotethyan and Huğlu-Pindos Series in the Lycian Nappes (SW Turkey): Geodynamical Implications," in The Triassic System. Editors L.H. Tanner, J.A. Spielmann, and SG. Lucas (New Mexico: Museum of Natural History \& Science Bulletins), 61, 401-444.

Neunzert, G. H., Gaupp, R., and Littke, R. (1996). Burial and Temperature of Paleozoic and Mesozoic Rocks in the Northwest German Basin. Zeitschrift der Deutschen Gesellschaft für Geowissenschaften 147, 183-208. doi:10.1127/zdgg/ $147 / 1996 / 183$

Nürnberger, T. (2010). Fazies und Genese der Stuttgart-Formation (Schilfsandstein) im Thüringer Becken und Thüringer Grabfeld. Diploma thesis. University of Jena, 92.

Ogg, J. G. (2015). The Mysterious Mid-carnian "Wet Intermezzo" Global Event. J. Earth Sci. 26, 181-191. doi:10.1007/s12583-015-0527-x

Parrish, J. T. (1993). Climate of the Supercontinent Pangea. J. Geology 101, 215-233. doi:10.1086/648217

Parrish, J. T. (1999). "Pangaea und das Klima der Trias," in Trias - eine ganz andere Welt. Editors N. Hauschke and V. Wilde (München: Pfeil), 81-104.

Patrick Muffler, L. J., and White, D. E. (1969). Active Metamorphism of Upper Cenozoic Sediments in the Salton Sea Geothermal Field and the Salton Trough, southeastern California. Geol. Soc. America Bull. 80, 157-182. doi:10.1130/ 0016-7606(1969)80[157:amoucs]2.0.co;2

Perry, E., and Hower, J. (1970). Burial Diagenesis in Gulf Coast Pelitic Sediments. Clays and Clay Minerals 18, 165-177. doi:10.1346/ccmn.1970.0180306

Preto, N., Kustatscher, E., and Wignall, P. B. (2010). Triassic Climates - State of the Art and Perspectives. Palaeogeogr. Palaeoclimatol. Palaeoecol. 290, 1-10. doi:10.1016/j.palaeo.2010.03.015

Rainbird, R. H., Hamilton, M. A., and Young, G. M. (2001). Detrital Zircon Geochronology and Provenance of the Torridonian, NW Scotland. J. Geol. Soc. 158, 15-27. doi:10.1144/jgs.158.1.15

Reinhardt, L., and Ricken, W. (2000). The Stratigraphic and Geochemical Record of Playa Cycles: Monitoring a Pangaean Monsoon-like System (Triassic, Middle Keuper, S. Germany). Palaeogeogr. Palaeoclimatol. Palaeoecol. 161, 205-227. doi:10.1016/s0031-0182(00)00124-3

Rodon, S., and Littke, R. (2005). Thermal Maturity in the Central European Basin System (Schleswig-Holstein Area): Results of 1D basin Modelling and New Maturity Maps. Int. J. Earth Sci. (Geol Rundsch) 94, 815-833. doi:10.1007/ s00531-005-0006-1

Roghi, G., Gianolla, P., Minarelli, L., Pilati, C., and Preto, N. (2010). Palynological Correlation of Carnian Humid Pulses throughout Western Tethys. Palaeogeogr. Palaeoclimatol. Palaeoecol. 290, 89-106. doi:10.1016/ j.palaeo.2009.11.006

Ruffell, A., Simms, M. J., and Wignall, P. B. (2015). The Carnian Humid Episode of the Late Triassic: a Review. Geol. Mag. 153, 271-284. doi:10.1017/ s0016756815000424

Salger, M. (1982). Mineralogie der Forschungsbohrung Dinkelsbühl 1001. Geologica Bavarica 83, 57-66.

Santos, M. M., Lana, C., Scholz, R., Buick, I., Schmitz, M. D., Kamo, S. L., et al. (2017). A New Appraisal of Sri Lankan BB Zircon as a Reference Material for LA-ICP-MS U-Pb Geochronology and Lu-Hf Isotope Tracing. Geostand Geoanal Res. 41, 335-358. doi:10.1111/ggr.12167

Schröder, B., (1977). Unterer Keuper und Schilfsandstein im germanischen TriasRandbecken. Zentralblatt für Geologie und Paläontologie, Teil I 1976, 1030-1056.

Segonzac, G. D. (1970). The Transformation of Clay Minerals during Diagenesis and Low-Grade Metamorphism: A Review. Sedimentology 15, 281-346. doi:10.1111/j.1365-3091.1970.tb02190.x 
Simms, M. J., and Ruffell, A. H. (1989). Synchroneity of Climatic Change and Extinctions in the Late Triassic. Geol 17, 265-268. doi:10.1130/00917613(1989)017<0265:soccae >2.3.co;2

Sláma, J., Košler, J., Condon, D. J., Crowley, J. L., Gerdes, A., Hanchar, J. M., et al. (2008). Plešovice Zircon - A New Natural Reference Material for U-Pb and $\mathrm{Hf}$ Isotopic Microanalysis. Chem. Geol. 249, 1-35. doi:10.1016/ j.chemgeo.2007.11.005

Stacey, J. S., and Kramers, J. D. (1975). Approximation of Terrestrial lead Isotope Evolution by a Two-Stage Model. Earth Planet. Sci. Lett. 26, 207-221. doi:10.1016/0012-821x(75)90088-6

Stampfli, G. M., and Borel, G. D. (2004). "The TRANSMED Transects in Space and Time: Constraints on the Paleotectonic Evolution of the Mediterranean Domain," in The TRANSMED Atlas. The Mediterranean Region from Crust to Mantle. Editors W. Cavazza, F. Roure, W. Spakman, G.M. Stampfli, and P.A. Ziegler (Berlin, Heidelberg: Springer), 53-80. doi:10.1007/978-3-64218919-7_3

Stampfli, G. M., Vavassis, I., De Bono, A., Rosselet, F., Matti, B., and Bellini, M. (2003). Remnants of the Paleotethys Oceanic Suture-Zone in the Westem Tethyan Area. Boll. Soc. Geol. It., Vol Spec. 2, 1-23.

Stollhofen, H., Bachmann, G. H., Barnasch, J., Bayer, U., Beutler, G., Franz, M., et al. (2008). "Upper Rotliegend to Lower Cretaceous basin Development," in Dynamics of Complex Sedimentary Basins: The Example of the Central European Basin System. Editors R. Littke, U. Bayer, D. Gajewski, and S. Nelskamp (Heidelberg: Springer), 157-180.

Storck, J.-C., Brack, P., Wotzlaw, J.-F., and Ulmer, P. (2019). Timing and Evolution of Middle Triassic Magmatism in the Southern Alps (Northern Italy). J. Geol. Soc. 176, 253-268. doi:10.1144/jgs2018-123

Sun, Y. D., Wignall, P. B., Joachimski, M. M., Bond, D. P. G., Grasby, S. E., Lai, X. L., et al. (2016). Climate Warming, Euxinia and Carbon Isotope Perturbations during the Carnian (Triassic) Crisis in South China. Earth Planet. Sci. Lett. 444, 88-100. doi:10.1016/j.epsl.2016.03.037

Thomson, S. N., and Zeh, A. (2000). Fission-track Thermochronology of the Ruhla Crystalline Complex: New Constraints on the post-Variscan thermal Evolution of the NW Saxo-Bohemian Massif. Tectonophysics 324, 17-35. doi:10.1016/ s0040-1951(00)00113-x

van Bergen, M. J., and Sissingh, W. (2007). "Magmatism in the Netherlands: Expression of the north-west European Rifting History," in Geology of the Netherlands. Editors T. E. Wong, D.A.J. Batjes, and J. de Jager (Royal Netherlands Academy of Arts and Sciences), 197-221.

Voigt, T., Grobleben, J., Schöner, R., and Gaupp, R. (2010). Die thermische Reife permokarboner Ablagerungen in Thüringen - Schlussfolgerungen für die Versenkungsgeschichte der Thüringer Mulde. Beitr. Geol. Thüringen, N.F. 17, 83-100.

Vollmer, T., Werner, R., Weber, M., Tougiannidis, N., Röhling, H.-G., and Hambach, U. (2008). Orbital Control on Upper Triassic Playa Cycles of the Steinmergel-Keuper (Norian): A New Concept for Ancient Playa Cycles.
Palaeogeogr. Palaeoclimatol. Palaeoecol. 267, 1-16. doi:10.1016/ j.palaeo.2007.12.017

Wilson, K. M., Pollard, D., Hay, W. W., Thompson, S. L., and Wold, C. N. (1994). General Circulation Model Simulations of Triassic Climates: Preliminary Results. Geol. Soc. Am. Spec. Paper 288, 91-116. doi:10.1130/spe288-p91

Wotzlaw, J.-F., Brack, P., and Storck, J.-C. (2018). High-resolution Stratigraphy and Zircon U-Pb Geochronology of the Middle Triassic Buchenstein Formation (Dolomites, Northern Italy): Precession-Forcing of Hemipelagic Carbonate Sedimentation and Calibration of the Anisian-Ladinian Boundary Interval. J. Geol. Soc. 175, 71-85. doi:10.1144/jgs2017-052

Wurster, P. (1964). Geologie des Schilfsandstein. Mitteilungen des Geologischen Staatsinstituts Hamburg 33, 140.

Wurster, P. (1968). Paläogeographie der deutschen Trias und die paläogeographische Orientierung der Lettenkohle in Südwestdeutschland. Eclogae Geologicae Helv. 61, 157-166.

Xu, G., Hannah, J. L., Stein, H. J., Mørk, A., Vigran, J. O., Bingen, B., et al. (2014). Cause of Upper Triassic Climate Crisis Revealed by Re-Os Geochemistry of Boreal Black Shales. Palaeogeogr. Palaeoclimatol. Palaeoecol. 395, 222-232. doi:10.1016/j.palaeo.2013.12.027

Zeh, A., and Gerdes, A. (2012). U-Pb and Hf Isotope Record of Detrital Zircons from Gold-Bearing Sediments of the Pietersburg Greenstone Belt (South Africa)-Is There a Common Provenance with the Witwatersrand Basin? Precambrian Res. 204-205, 46-56. doi:10.1016/j.precamres.2012.02.013

Zhang, Y., Ogg, J. G., Franz, M., Bachmann, G. H., Szurlies, M., Röhling, H.-G., et al. (2020). Carnian (Late Triassic) Magnetostratigraphy from the Germanic Basin Allowing Global Correlation of the Mid-carnian Episode. Earth Planet. Sci. Lett. 541, 116275. doi:10.1016/j.epsl.2020.116275

Ziegler, P. A. (1990). Geological Atlas of Western and Central Europe. Den Haag: Shell International Petroleum Maatschapij BV.

Conflict of Interest: The authors declare that the research was conducted in the absence of any commercial or financial relationships that could be construed as a potential conflict of interest.

Publisher's Note: All claims expressed in this article are solely those of the authors and do not necessarily represent those of their affiliated organizations, or those of the publisher, the editors and the reviewers. Any product that may be evaluated in this article, or claim that may be made by its manufacturer, is not guaranteed or endorsed by the publisher.

Copyright (c) 2021 Zeh, Franz and Obst. This is an open-access article distributed under the terms of the Creative Commons Attribution License (CC BY). The use, distribution or reproduction in other forums is permitted, provided the original author(s) and the copyright owner(s) are credited and that the original publication in this journal is cited, in accordance with accepted academic practice. No use, distribution or reproduction is permitted which does not comply with these terms. 